Review Article

\title{
Stromal Vascular Fraction and Amniotic Epithelial Cells: Preclinical and Clinical Relevance in Musculoskeletal Regenerative Medicine
}

\author{
Francesca Veronesi $\left(\mathbb{D},{ }^{1}\right.$ Melania Maglio $\mathbb{D}^{1},{ }^{1}$ Deyanira Contartese $\mathbb{D}^{1},{ }^{1}$ Lucia Martini $\mathbb{D}$, \\ Aurelio Muttini $\left(\mathbb{D},{ }^{2}\right.$ and Milena Fini $\left(\mathbb{C}^{1}\right.$ \\ ${ }^{1}$ IRCCS Istituto Ortopedico Rizzoli, Complex Structure of Surgical Sciences and Technologies, Via di Barbiano 1/10, \\ 40136 Bologna, Italy \\ ${ }^{2}$ Faculty of Bioscience and Agro-Food and Environmental Technology, University of Teramo, Italy \\ Correspondence should be addressed to Melania Maglio; melania.maglio@ior.it
}

Received 5 November 2020; Revised 31 December 2020; Accepted 6 February 2021; Published 22 February 2021

Academic Editor: Elena Jones

Copyright (c) 2021 Francesca Veronesi et al. This is an open access article distributed under the Creative Commons Attribution License, which permits unrestricted use, distribution, and reproduction in any medium, provided the original work is properly cited.

\begin{abstract}
Musculoskeletal regenerative medicine is mainly based on the use of cell therapy to heal damaged tissues such as bone, cartilage, and tendons. Throughout the years, different cell types have been employed for the treatment of musculoskeletal diseases, in particular, mesenchymal stem cells (MSCs) derived from bone marrow (BMSCs) and adipose tissue (ADSCs). Though the results of these literature studies have been encouraging, there are some limitations, especially on long-term results. Recently, some interest has shifted towards new cell types such as the stromal vascular fraction (SVF) and amniotic endothelial cells (AECs). The aim of the present literature review is to evaluate preclinical and clinical studies that used SVF and AECs for musculoskeletal tissue regeneration. Forty-eight preclinical and clinical studies, performed in the last 10 years, were identified. Both SVF and AECs, injected or implanted with or without scaffolds, were shown to be valid alternatives, and in some ways superior, to ADSCs and BMSCs, being able to differentiate towards osteogenic, chondrogenic, and tenogenic lineages, and to promote cell and tissue regenerative potential. The use of SVF and AECs could represent a new regenerative treatment in several musculoskeletal pathologies, solving the problem of cell expansion in vitro.
\end{abstract}

\section{Introduction}

In several musculoskeletal tissue diseases that affect the cartilage, tendons, and bone, there is the need for new regenerative treatments instead of traditional conservative or surgical therapeutic approaches that mainly give palliative care or short-term curative effects [1-3]. In this regard, mesenchymal stem cells (MSCs) have been employed as substitutes and as a promising therapeutic strategy to restore tissue biology, having success in several pathologies, even if the ideal source of stem cells is still debated. In the ambit of cellular therapies, MSCs play a leading role because they possess paracrine activity, through which they exert anti-inflammatory, antiapoptotic, antifibrotic, proangiogenic, and mitogenic activities on the microenvironment, adjacent tissues, and cells [4]. Different tissues have been identified as a source of MSCs, and among them, MSCs from bone marrow (BMSCs) have been mostly used for the regeneration of musculoskeletal tissues, achieving satisfactory results [5]. However, MSCs from adipose tissue (ADSCs) show advantages over BMSCs: ADSCs are reported to have higher genetic stability and higher proliferation, differentiation, and immunoregulatory abilities, and they also show lower senescence than BMSCs [6, 7]. The clinical use of MSCs could be complicated due to donor site morbidity, ageing or disease of the donor, and the necessity of a previous in vitro expansion to obtain a large cell number able to produce a clinical effect (it is estimated that nearly $10 \times 10^{7}$ cells should produce a clinically appreciable effect) with associated risks of cell transformation or infection, replaced by a one-step procedure with bone marrow [8]. 
With particular reference to therapies aimed at skeletal muscle regeneration, other cellular sources have also been tested, including mesoangioblasts, derived from blood vessels, or fibro/adipogenic progenitors (FAPs), multipotent mesenchymal cells derived from skeletal muscle. Mesoangioblasts are multipotent mesodermal progenitor cells that can be isolated by fetal muscle biopsy [9]. FAPs are involved in a dynamic crosstalk with the other cellular populations of the muscle stem cell niche, in particular, immediately after injury occurrence [10]. However, isolation of FAPs requires the application of a long and complex protocol, including muscle dissection or digestion, and subsequent characterization with antibody staining and cell sorting [11].

In an effort to find a smarter cell substitute for MSCs, the stromal vascular fraction (SVF) has been characterized to be employed in preclinical and clinical scenarios [12]. SVF includes not only ADSCs but also a heterogeneous group of cells, such as progenitor cells, endothelial cells, fibroblasts, monocytes, macrophages, immune cells, muscle cells, pericytes, CD34+ cells, growth factors (GFs), a few adipocytes, and stromal components [13]. Similar to MSCs, SVF is proangiogenic and immunomodulatory, and its cellular components are able to differentiate and proliferate, all of the features that make it suitable for tissue regeneration [14]. The advantage of using SVF with respect to expanded ADSCs is immediately clear since SVF, obtained with collagenase digestion and centrifugation of adipose tissue, can be easily harvested from a patient through lipoaspiration. Moreover, it is autologous, requires minimal manipulation, and contains ADSCs at a percentage ranging from 0.06 to 4 CFU-f. Therefore, SVF could be injected directly into a damaged tissue reducing inflammation and promoting regeneration, with consequent reduction in health costs and hours of hospitalization $[15,16]$. Indeed, SVF allows the socalled one-step surgical procedure, through which it is possible to harvest and implant SVF in the same surgical session, not requiring in vitro expansion. This procedure consists of minimal cell manipulation and low risks linked to culture, without specific regulatory requirements for clinical translation, thus accelerating surgery. The process that goes from surgical adipose tissue harvest, SVF production, and its seeding onto a scaffold or onto hydrogels or its direct injection, lasts at most 4 hours $[17,18]$.

Another innovative cell source was found in the human placenta, a waste material with cells characterized by high plasticity [19]. The amniotic membrane is obtained from the placenta without an invasive procedure and could be employed as an autologous or allogenic graft due to its immunomodulation properties $[20,21]$. The amniotic endothelial cells (AECs) are considered a valid alternative to MSCs because they differentiate into three lineages (osteogenic, adipogenic, and chondrogenic), express mesenchymal and embryonic stem cell markers, show a nontumorigenic phenotype, and have a high yield in terms of in vitro expansion. In addition, AECs replace embryonic stem cells that show a clear impact on ethical matters [22].

Currently, while BMSCs are widely analysed in musculoskeletal pathologies, little is known on the use of SVF and AECs as cell therapies for the regeneration of musculoskeletal diseases especially in comparison with other common cell types and sources [23-26]. These cells were mostly characterized in vitro and sporadically compared with other cell types, despite exhibiting noninferior characteristics [27]. However, considering the advantages of the fact that the source of these cells is waste material, which does not include any kind of sampling, it would be interesting to compare them with SVF, whose use in regenerative medicine is very promising, though require a more demanding harvesting. The aim of this review is to collect preclinical and clinical studies, performed in the last 10 years, which used SVF or AECs in bone, cartilage, and tendon tissue regeneration.

\section{Materials and Methods}

The review has been performed according to the Preferred Reporting Items for Systematic Reviews and Meta-Analyses (PRISMA) statement. The studies included in the present review were identified through the http://www.pubmed .com/ and http://www.webofknowledge.com/ databases. In the first database, the keywords used were the following: "(amniotic epithelial stem cells OR stromal vascular fraction) AND (tendon OR cartilage OR bone OR ligament)." The limits were use of English language and publication date from $2010 / 01 / 01$ to $2019 / 06 / 31$. In the second database, the keywords were the same, but the limits were use of English language, publication date from 2010 to 2019, and document type was article.

A total of 284 articles were found using the http://www .pubmed.com/ database, and from among them, 242 articles were excluded because they were reviews; or they were focused on cell isolation techniques; or they were not related to musculoskeletal tissues but were related to the heart, corneal epithelium, liver, skin, or bladder; or they were concerned with culture-expanded ADSCs, BMSCs, embryonic stem cells, or MSCs derived from amniotic fluid. Therefore, forty-two studies were accepted.

A total of 452 articles were found using http://www .webofknowledge.com/, and of these, 449 were excluded because they were not inherent, or they were reviews, or they overlapped with the previous search (38 studies). Therefore, three studies were accepted.

In addition, after reading the reference lists of the accepted studies, another six articles were included. Therefore, a final total of 51 studies were taken into consideration (Figure 1).

\section{Results}

Most of the studies (35/51 studies) dealt with SVF [7, 14, 25-57], and 16/51 studies dealt with AECs [58-73] (Figure 2).

The 35 studies on SVF were conducted to treat bone (no of studies: 16) [17, 28-42], cartilage (no of studies: 13) [7, 4354], and tendon (no of studies: 6) [55-60] defects (Figure 2). They were conducted in vitro $[17,28-30,43]$ and in vivo $[7$, $29,31-39,42-45,55-58]$, and some of them were clinical studies [40-43, 46-54, 59, 60].

Regarding AECs, seven studies were performed on bone [61-67], 2 on cartilage $[68,69]$, and 7 on tendon [70-76] 


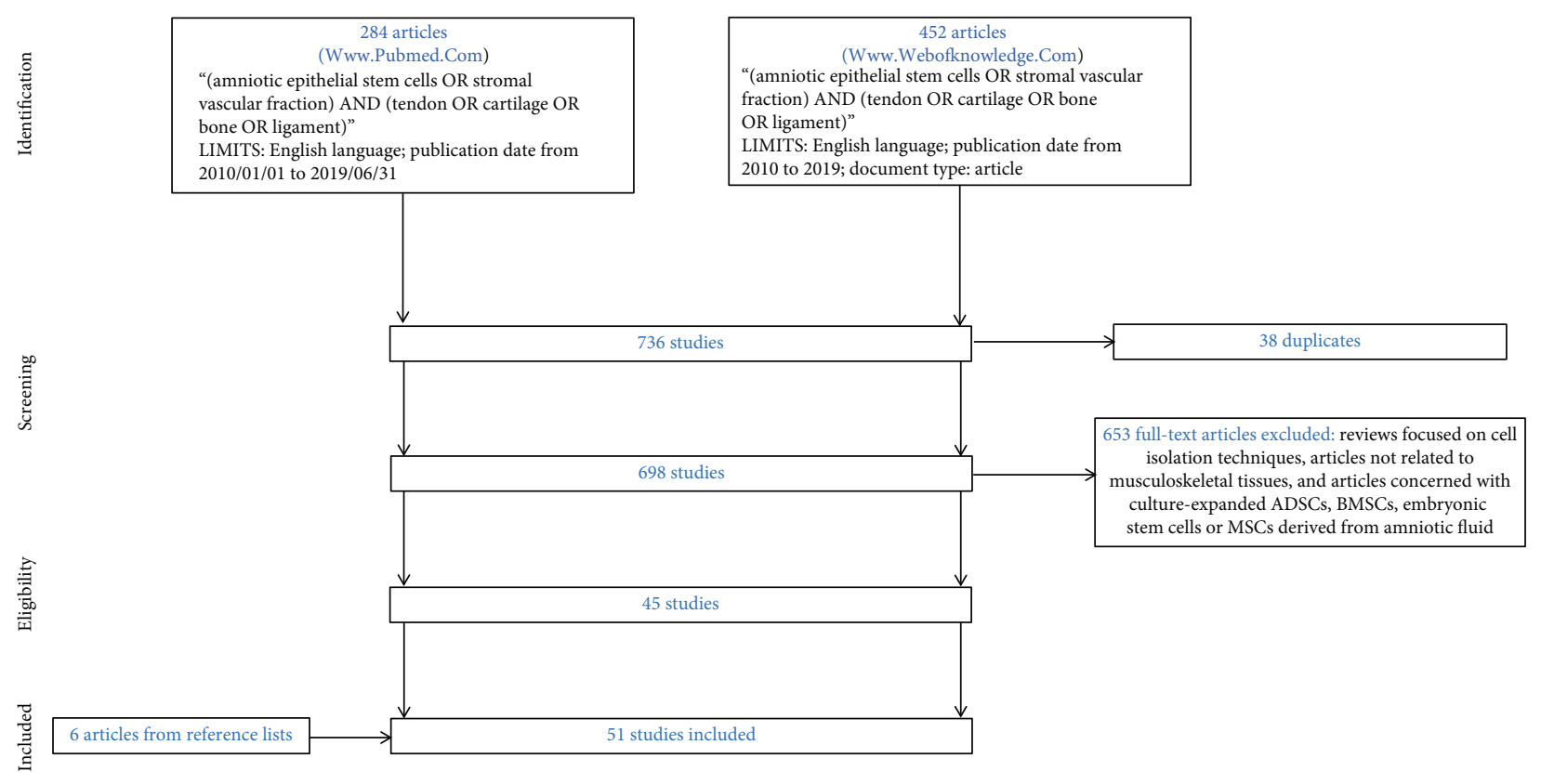

FIGURE 1: Schematic representation of the search strategy.

defects. Among these 13 studies, some were carried out in vitro $[61-64,68-70]$ and others in vivo [65-67, 71-76] (Figure 2).

In addition, 11 studies compared two or more cell types in the same study $[7,17,28,29,35,43,44,56,61,67,68]$. More precisely, SVF were compared with the following: (1) BMSCs [28, 56], in vitro [28] and in vivo in rabbit tendon regeneration [56]; (2) ADSCs [7, 17, 35, 44], in vitro [17] and in vivo in mouse bone defect [35], goat osteochondral defects [44], and sheep knee osteoarthritis (OA) [7]; and (3) monocyte cell line (THP1) and ADSCs [29] or chondrocytes and ADSCs [43] in rat bone defects [29] or mouse subcutaneous pouches [43].

AECs were directly compared with the following: (1) ADSCs in vitro [61]; (2) BMSCs and amniotic fluid MSCs (AFMSCs) in mouse subcutaneous pouches [67]; and (3) chondrocytes, BMSCs, and amniotic MSCs (AMSCs) in vitro [68].

\subsection{SVF and Bone}

3.1.1. In Vitro Studies. Four in vitro studies were performed with human SVF (hSVF) obtained from subcutaneous tissue [29] or nonspecified sites [17, 28, 30] of donors (Table 1).

In the first study, ALP activity and gene expression of Runt-related transcription factor 2 (RUNX2), collagen I (COLL I), alkaline phosphatase (ALP), and Osterix (OSX) of human BMSCs (hBMSCs) significantly increased when cocultured with hSVF in comparison to hBMSCs cultured alone [28].

In another study, ALP activity and calcium content of THP1 increased more when cocultured with hSVF than with hADSCs, after two and four weeks of culture. Additionally, in this study, hSVF or hADSCs alone or combined with THP1 cells were implanted in bone defects in femoral condyles of
46 nude rats. Ten weeks after implanting, it was observed that hSVF increased significantly more bone area (BA) than hADSCs [29].

Two types of scaffolds, namely, poly(L-lactide-co-caprolactone) (PLCL) and COLL I/COLL III, were seeded with hSVF and cultured in normal (NM), chondrogenic (CM), or osteogenic (OM) media to observe hSVF differentiation. The expression of sex-determining region Y box 6 (SOX6) and SOX9 significantly increased when the PLCL construct was cultured in CM. Gene expression of ALP, osteonectin, and COLL I increased when it was cultured in OM. Aggrecan gene expression increased when hSVF was cultured on PLCL, while COLL II gene expression increased with the COLL I/COLL III scaffold [30].

Finally, in another study, hSVF was cultured on a xenohybrid bone graft and compared with hADSCs. hSVF induced the formation of more bone trabeculae than hADSCs after 2 months of culture [14].

3.1.2. In Vivo Studies. Four in vivo studies were conducted in subcutaneous or muscular pouches of nude rats [31], athymic mice [32], nude mice [33], and syngenic mice [34]. SVF was obtained from the abdomen or breast [32], epididymis [34], or nonspecified sites $[31,33]$ of human donors (Table 1 ).

In one study, a hydroxyapatite (HA) scaffold was implanted alone or combined with hSVF. The addition of hSVF increased vessel number and M2 macrophages after 1 week and bone volume (BV) after 2 months [31].

In another study, beta-tricalcium phosphate ( $\beta \mathrm{TCP})$ or HA scaffolds were seeded with hSVF at 3 different concentrations $\left(<2 \times 10^{6} \mathrm{CFU}-\mathrm{f} / \mathrm{cm}^{3},>2 \times 10^{6} \mathrm{CFU}-\mathrm{f} / \mathrm{cm}^{3}\right.$, or $>3 \times 10^{6}$ CFU-f $\left./ \mathrm{cm}^{3}\right)$. After 2 months from implantation, both scaffolds, seeded with hSVF at concentrations of $>2 \times 10^{6} \mathrm{CFU}$ $\mathrm{f} / \mathrm{cm}^{3}$ or $>3 \times 10^{6} \mathrm{CFU}-\mathrm{f} / \mathrm{cm}^{3}$, increased the formation of dense matrix [32]. An increase in mineralized volume, BA, 


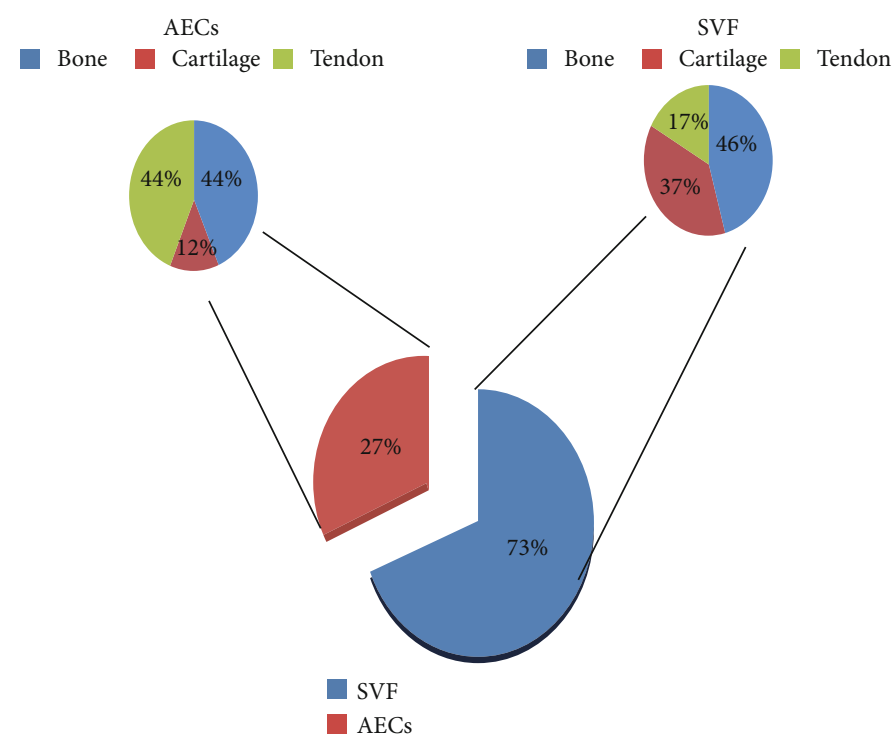

(a)

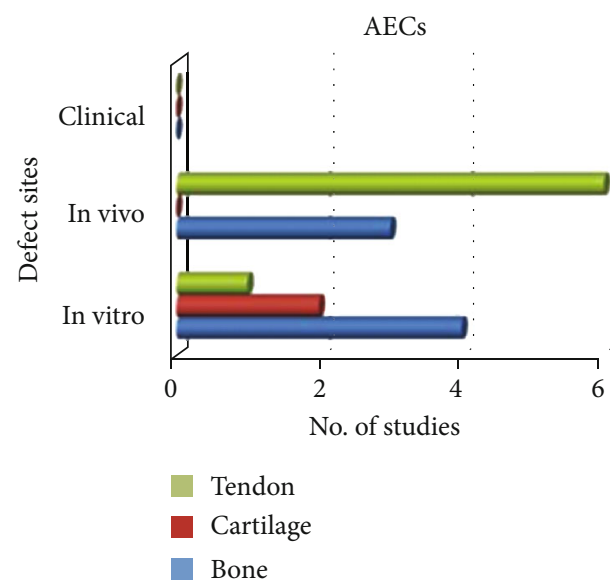

(b)

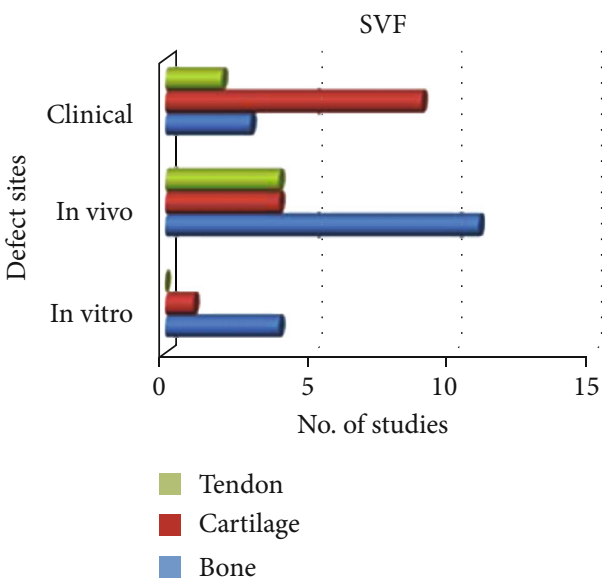

(c)

FIgure 2: Amount of in vitro, in vivo, and clinical studies. (a) Pie chart of the percentages of the literature studies on SVF (blue: 73\%) and AECs (red: 27\%). In addition, the other two pie charts for each type of cell present the percentages of literature studies on bone (blue), cartilage (red), and tendon (green) regeneration. (b) Bar graph on the number of clinical, in vivo, and in vitro studies found in the literature, for the regeneration of bone (blue), cartilage (red), and tendon (green) by AECs. (c) Bar graph on the number of clinical, in vivo, and in vitro studies found in the literature, for the regeneration of bone (blue), cartilage (red), and tendon (green) by SVF.

osteoid matrix formation, and vessel length was observed 3 months after the implantation of a devitalized hypertrophic cartilage pellet with hSVF at a concentration of $6 \times 10^{6} / \mathrm{ml}$ or $12 \times 10^{6} / \mathrm{ml}$ in comparison to a concentration of $24 \times 10^{6}$ $/ \mathrm{ml}$. Moreover, BA was significantly higher in nude rats with bilateral parietal bone defects treated with a scaffold and hSVF than with a scaffold alone after 1 month [33].

Najman et al. implanted a deproteinized sterilized bovine bone scaffold alone or combined with autologous SVF and platelet-rich plasma (PRP). Evaluations were performed after $1,2,4$, and 8 weeks when it was observed that SVF and PRP significantly increased osteopontin (OPN) protein levels; gene expression of OSX, COLL I, ALP, and osteocalcin (OCN); osteoid-like tissue formation; and vascularization compared to a scaffold alone [34].
The other 5 in vivo studies were performed in critically sized calvaria defects in nude mice [35] or in rats [35], in segmental bone defects in the middiaphysis of the left ulna of rabbits [37], in osteonecrosis jaw- (ONJ-) like defects of mice [38], and in the right carpal bone of 1 horse [37]. SVF was obtained from the flank, scapula, abdomen, inner thigh [35], inguinal region [36], and gluteal muscle [39], and used as autologous [36, 39], allogenic [37, 38], or xenogenic grafts [32] (Table 1).

Both hSVF and hADSCs, seeded onto a polycaprolactonedecellularized bovine bone extracellular matrix (PCL-DCB) scaffold, increased BV more than the scaffold alone; in addition, hSVF increased BV during time, up to 3 months, in critically sized defects. In the same study, the PCL-DCB scaffold, seeded with hSVF and hADSCs, was also implanted 
TABLE 1: In vitro, in vivo, and clinical studies on SVF in bone regeneration.

\begin{tabular}{|c|c|c|c|c|}
\hline Materials & Treatment groups & Evaluations & Results & Ref \\
\hline $\begin{array}{l}\text { In vitro: } \\
\text { hSVF from } 4 \text { donors }(42-62 \mathrm{yrs}) \\
\left(5 \times 10^{4}\right) \\
\text { Purchased hBMSCs }\left(5 \times 10^{4}\right)\end{array}$ & $\begin{array}{c}\text { Group 1: BMSCs } \\
\text { Group 2: BMSCs+SVF }\end{array}$ & $\begin{array}{c}\text { ALP activity } \\
\text { RT-PCR (RUNX2, } \\
\text { COLL I, ALP, and OSX) }\end{array}$ & $\begin{array}{c}12,24 \text {, and } 48 \mathrm{hrs} \\
\text { Group 2: } \uparrow \text { gene expression than group } 1 \\
24 \text { and } 48 \text { hrs } \\
\text { Group 2: } \uparrow \text { ALP activity than group } 1\end{array}$ & [28] \\
\hline $\begin{array}{l}\text { In vitro: } \\
\text { hSVF }\left(3 \times 10^{6}\right) \text { or hADSCs } \\
\left(1 \times 10^{6}\right) \text { from subcutis of } 3 \text { donors } \\
(38-52 \text { yrs }) \\
\text { THP1 }\left(1 \times 10^{6}\right) \\
\text { In vivo: } \\
46 \text { nude rats with bilateral bone } \\
\text { defects }(3 \times 3 \mathrm{~mm}) \text { in femoral } \\
\text { condyles } \\
\text { hSVF }\left(3 \times 10^{6}\right) \text { or hADSCs } \\
\left(1 \times 10^{6}\right) \text { from abdomen } \\
\text { THP1 }\left(1 \times 10^{6}\right)\end{array}$ & $\begin{array}{c}\text { In vitro: } \\
\text { Group 1: THP1 } \\
\text { Group 2: SVF } \\
\text { Group 3: THP1+SVF } \\
\text { Group 4: ADSCs } \\
\text { Group 5: } \\
\text { THP1+ADSCs } \\
\text { In vivo: } \\
\text { Group 1: no treatment } \\
\text { Group 2: THP1 } \\
\text { Group 3: SVF } \\
\text { Group 4: THP1+SVF } \\
\text { Group 5: ADSCs } \\
\text { Group 6): } \\
\text { THP1+ADSCs }\end{array}$ & $\begin{array}{c}\text { In vitro: } \\
\text { ALP activity } \\
\text { Calcium content } \\
\text { In vivo: } \\
\text { Histology } \\
\text { Histomorphometry }\end{array}$ & $\begin{array}{c}\text { In vitro: } \\
2 \text { wks } \\
\text { Group 3: } \uparrow \text { ALP activity than } \\
\text { groups } 2,4 \text {, and } 5 \text {. } \\
1 \text { mo } \\
\text { Group 3: } \uparrow \text { calcium content than } \\
\text { groups } 2 \text { and } 5 \\
\text { In vivo: } \\
4 \text { and } 10 \text { wks } \\
\text { Groups 3, } 4,5 \text {, and } 6: \uparrow \text { BA/TA than } \\
\text { groups } 1 \text { and } 2 \text {. } \\
10 \text { wks } \\
\text { Groups } 3 \text { and } 4: \uparrow \text { BA/TA than } \\
\text { groups } 5 \text { and } 6\end{array}$ & [29] \\
\hline $\begin{array}{l}\text { In vitro: } \\
\text { hSVF }\left(2 \times 10^{6}\right) \text { from } 8 \text { donors } \\
(39.8 \pm 9.7 \mathrm{yrs}) \\
\text { PLCL scaffold } \\
\text { COLL I/COLL III scaffold }\end{array}$ & $\begin{array}{l}\text { Group 1: } P L C L+S V F \text { in } \\
\text { NM } \\
\text { Group 2: COLL I/COLL } \\
\text { III+SVF in NM } \\
\text { Group 3: PLCL+SVF in } \\
\text { CM } \\
\text { Group 4: } \text { PLCL+SVF in } \\
\text { OM } \\
\text { Group 5: COLL I/COLL } \\
\text { III+SVF in CM } \\
\text { Group 6: COLL I/COLL } \\
\text { III+SVF in OM }\end{array}$ & $\begin{array}{l}\text { RT-PCR (ACAN, SOX6, } \\
\text { SOX9, ALP, ONC, } \\
\text { COLL I, COLL III, and } \\
\text { COLL X) }\end{array}$ & $\begin{array}{c}4 \text { days } \\
\text { Group 3: } \uparrow \text { ACAN gene expression } \\
\text { than group 5) } \\
2 \text { wks } \\
\text { Groups } 3 \text { and 5: } \uparrow \text { SOX6, SOX9 } \\
\text { gene expression during time } \\
\text { Groups } 4 \text { and 6: } \uparrow \text { ALP, ONC, and } \\
\text { COLL I gene expression during time } \\
3 \text { wks } \\
\text { Group 5: } \uparrow \text { COLL II gene expression } \\
\text { than group } 3 \\
\text { Groups } 3 \text { and 5: } \downarrow \text { COLL X gene } \\
\text { expression during time }\end{array}$ & [30] \\
\hline
\end{tabular}

Group 1: SVF in plastic in $\mathrm{NM}$

Group 2: ADSCs in plastic in NM

Group 3: scaffold+SVF

In vitro: in NM

hSVF or hADSCs $\left(1 \times 10^{6}\right)$ from 7 Group 4: donors Xenohybrid bone graft scaffold $(7 \times 3 \mathrm{~mm})$

scaffold+ADSC in NM

Group 5: SVF in plastic in $\mathrm{OM}$

Group 6: ADSCs in plastic in $\mathrm{OM}$

Group 7: scaffold+SVF in $\mathrm{OM}$ Group 8: scaffold+ADSC in OM

In vivo:

28 nude rats with subcutaneous pouch hSVF $\left(12 \times 10^{6}\right)$ from 5 donors $(43 \pm 12$ yrs $)$

HA scaffold ( $1 \mathrm{~cm}$ diameter, $1 \mathrm{~cm}$
Group 1: scaffold Group 2: scaffold+SVF previously cultured for 5 days
$2 \mathrm{mo}$
Micro-CT

IHC (OCN)

ALP activity

Mineralization height)

height)

\section{$1 \mathrm{wk}$}

Micro-CT

Histomorphometry
Group 2: $\uparrow$ vessel number, M2 macrophages than group 1 2 mo

Group 2: $\uparrow$ BV/TV than group 1 $7: \uparrow$ bone trabeculae
groups 4,8 , and 3

Groups 3 and 4: $\downarrow$ OCN than groups 7 and 8 [17] Group 1: $\uparrow$ ALP activity than group 2 Groups 1 and 2: $\downarrow$ mineralization than groups 5 and 6 
TABle 1: Continued.

\begin{tabular}{|c|c|c|c|c|}
\hline Materials & Treatment groups & Evaluations & Results & Ref \\
\hline $\begin{array}{l}\text { In vivo: } \\
\mathrm{CD} 1^{\text {nu/nu }} \text { athymic mice with } \\
\text { subcutaneous pouches } \\
\text { hSVF from abdomen or breast of } \\
\text { donors ( } 32 \pm 15 \mathrm{yrs}) \\
\beta \mathrm{TCP} \text { scaffold ( } 8 \mathrm{~mm} \text { diameter, } \\
4 \mathrm{~mm} \text { height) } \\
\text { HA scaffold ( } 8 \mathrm{~mm} \text { diameter, } \\
4 \mathrm{~mm} \text { height) }\end{array}$ & $\begin{array}{c}\text { Group 1: } \beta \mathrm{TCP}+\mathrm{SVF} \\
\left(>2 \times 10^{6} \mathrm{CFU}-\mathrm{f} / \mathrm{cm}^{3}\right) \\
\text { Group 2: } \beta \mathrm{TCP}+\mathrm{SVF} \\
\left(<2 \times 10^{6} \mathrm{CFU}-\mathrm{f} / \mathrm{cm}^{3}\right) \\
\text { Group 3: } \beta \mathrm{TCP}+\mathrm{SVF} \\
\left(>3 \times 10^{6} \mathrm{CFU}-\mathrm{f} / \mathrm{cm}^{3}\right) \\
\text { Group 4: } \mathrm{HA}+\mathrm{SVF} \\
\left(>2 \times 10^{6} \mathrm{CFU}-\mathrm{f} / \mathrm{cm}^{3}\right) \\
\text { Group 5: } \mathrm{HA}+\mathrm{SVF} \\
\left(<2 \times 10^{6} \mathrm{CFU}-\mathrm{f} / \mathrm{cm}^{3}\right) \\
\text { Group } 6: \mathrm{HA}+\mathrm{SVF} \\
\left(>3 \times 10^{6} \mathrm{CFU}-\mathrm{f} / \mathrm{cm}^{3}\right)\end{array}$ & Histology & $\begin{array}{c}2 \text { mo } \\
\text { Groups } 1,4,3 \text {, and } 6: \uparrow \text { dense } \\
\text { matrix than groups } 2 \text { and } 5 \\
\text { Groups } 3 \text { and } 6: \uparrow \text { dense matrix } \\
\text { similar to osteoid than groups } 1 \text { and } 4\end{array}$ & {$[32]$} \\
\hline
\end{tabular}

In vivo:

Nude mice with subcutaneous pouches

Nude rats with bilateral defects in parietal bone $(4 \mathrm{~mm})$

Devitalized hypertrophic cartilage pellet from 5 donors $(35.4 \pm 11.3 \mathrm{yrs})$

hSVF from 12 donors $(33.7 \pm 7.7 \mathrm{yrs})$
Group 1: pellet in pouches

Group 2: pellet+SVF

$\left(6 \times 10^{6} / \mathrm{ml}\right)$ in pouches

Group 3: pellet+SVF

$\left(12 \times 10^{6} / \mathrm{ml}\right)$ in pouches

Group 4: pellet+SVF

$\left(24 \times 10^{6} / \mathrm{ml}\right)$ in pouches

Group 5: pellet in bone defects

Group 6: pellet+SVF

$\left(12 \times 10^{6} / \mathrm{ml}\right)$ in bone defects
$3 \mathrm{mo}$

Group 3: $\uparrow$ mineralized volume, BA than group 1

Groups 2 and 3: $\uparrow$ vessel length density than group 1

1 mo

Group 6: $\uparrow$ BA than group 5
2 wks

Group 2: $\uparrow$ OPN protein than group 1 2 and $4 \mathrm{wks}$

In vivo:

24 syngenic Balb/c mice (8 wks) with subcutaneous pouches Autologous SVF $\left(5 \times 10^{5}\right)$ from epididymis

Bio-Oss ${ }^{\circledR}$ scaffold (deproteinized sterilized bovine bone) (10 mg)
Group 1: scaffold Group 2: scaffold+SVF+PRP
Histology

IHC (OPN)

Histomorphometry RT-PCR (OSX, OCN, COLL I, and ALP)
Group 2: $\uparrow$ COLL I gene expression than group 1

$$
2 \mathrm{mo}
$$

Group 2: $\uparrow$ ALP gene expression, osteoid-like tissue, OPN protein, vascularization than group 1

\section{In vivo:}

14 nude immunocompromised mice ( 8 wks) with bilateral critically sized calvarial defects Nude mice with muscular pouches hSVF or hADSCs $\left(2 \times 10^{4}\right)$ from flank, scapula, abdomen, or inner thigh of donors

PCL-DCB scaffold (4 mm diameter, $0.64 \mathrm{~mm}$ length)

\section{Group 1: scaffold in} bone defect

Group 2: scaffold+SVF in bone defect Group 3: scaffold+ADSCs in bone defect

Group 4: scaffold in pouches

Group 5: scaffold+SVF in pouches Group 6: scaffold+ADSCs in pouches
$3 \mathrm{mo}$

Groups 2 and 3: $\uparrow$ BV than group 1

Group 2: $\uparrow$ BV during time

Micro-CT

Histology

Group 5: $\uparrow$ VA than groups 4 and 6 Groups 5 and 6: $\uparrow$ VA than group 4 10 days 6 wks 
Table 1: Continued.

\begin{tabular}{|c|c|c|c|c|}
\hline Materials & Treatment groups & Evaluations & Results & Ref \\
\hline $\begin{array}{l}\text { In vivo: } \\
50 \text { SD rats }(8 \mathrm{wks}) \text { with critically } \\
\text { sized calvarial defects } \\
\text { Autologous SVF }\left(1 \times 10^{5}\right) \text { from } \\
\text { inguinal region } \\
\text { DBM scaffold } \\
\text { PLA scaffold }\end{array}$ & $\begin{array}{l}\text { Group 1: no treatment } \\
\text { Group 2: DBM } \\
\text { Group 3: DBM+SVF } \\
\text { Group 4: DBM+PLA } \\
\text { Group 5: } \\
\text { DBM+PLA+SVF }\end{array}$ & $\begin{array}{l}\text { Gross evaluations } \\
\text { Histology } \\
\text { IHC }(\mathrm{OCN})\end{array}$ & $\begin{array}{l}2 \text { mo } \\
\text { Groups } 3 \text { and 5: } \uparrow \text { defect filling, BA, OCN } \\
\text { than groups } 1,2 \text {, and } 4 \\
\text { Group 2: } \uparrow \text { defect filling than groups } 1 \text { and } 4 \\
\text { Group } 4: \uparrow \text { defect filling than group } 1\end{array}$ & [36] \\
\hline $\begin{array}{l}\text { In vivo: } \\
15 \mathrm{NZW} \text { rabbits }(14-16 \mathrm{wks}) \text { with } \\
\text { unilateral segmental bone defect in } \\
\text { the middiaphysis of left ulna } \\
(20 \mathrm{~mm}) \\
\text { Allogenic SVF }\left(1 \times 10^{6}\right) \text { from } \\
\text { suprascapular region } \\
\text { PLGA scaffold }(4 \times 20 \mathrm{~mm})\end{array}$ & $\begin{array}{l}\text { Group 1: scaffold } \\
\text { Group 2: scaffold+SVF } \\
\text { Group 3: } \\
\text { scaffold+osteogenically } \\
\text { differentiated SVF }\end{array}$ & $\begin{array}{l}\text { Radiography } \\
\text { Micro-CT } \\
\text { Histology }\end{array}$ & $\begin{array}{c}2 \text { mo } \\
\text { Group 3: defect bridging, trabecular bone } \\
\text { with smooth margins } \\
\text { Group 3: } \uparrow \text { BVF than groups } 1 \text { and } 2 \\
\text { Group 3: } \uparrow \text { Tb.Th than group 1 } \\
\text { Groups 2 and 3: scaffold absorbed } \\
\text { Group 2: } \uparrow \text { BVF than group } 1\end{array}$ & [37] \\
\hline $\begin{array}{l}\text { In vivo: } \\
28 \text { C57BL/6J mice }(8-12 \text { wks old }) \\
\text { with bilateral ONJ-like lesions } \\
\text { Allogenic SVF }\left(4 \times 10^{6}\right) \text { from } \\
\text { inguinal region }\end{array}$ & $\begin{array}{l}\text { Group 1: saline } \\
\text { Group 2: SVF }\end{array}$ & $\begin{array}{c}\text { Micro-CT } \\
\text { Histology } \\
\text { Histomorphometry }\end{array}$ & $\begin{array}{c}2 \text { and } 4 \text { wks } \\
\text { Group 2: } \uparrow \text { BA, osteocytes, bone filling, } \\
\text { Tb.Th, BMD, collagen fibers, blood vessels, } \\
\text { VA, F } 4 / 80^{+} \text {macrophages; } \downarrow \text { necrotic BA, } \\
\text { empty lacunae, Tb.Sp, PMN infiltration than } \\
\text { group } 1\end{array}$ & [38] \\
\hline $\begin{array}{l}\text { In vivo: } \\
1 \text { thoroughbred gelding in training } \\
(5 \text { yrs) with lameness of the right } \\
\text { carpal bone } \\
\text { Autologous SVF }\left(20 \times 10^{6}\right) \text { from } \\
\text { region above dorsal gluteal } \\
\text { muscles }\end{array}$ & Group 1: SVF & $\begin{array}{l}\text { Clinical evaluation } \\
\text { Lameness evaluation }\end{array}$ & $\begin{array}{l}\text { Group 1: return to racing } \\
20 \text { mo } \\
\text { Group 1: no injuries, no lameness, } \\
\text { high performance level }\end{array}$ & [39] \\
\hline $\begin{array}{l}\text { Clinical trial: } \\
10 \mathrm{pz} \text { ( } 46-69 \text { yrs old) partially } \\
\text { edentulous requiring bilateral or } \\
\text { unilateral dental implants } \\
\text { Autologous SVF }\left(10^{7} \text { nucleated }\right. \\
\text { cells) } \\
\beta \text { TCP scaffold } \\
\text { BCP (HA/ } \beta \text { TCP } 60 \% / 40 \%) \\
\text { scaffold }\end{array}$ & $\begin{array}{c}\text { Group 1: } \beta \mathrm{TCP} \\
\text { Group 2: } \beta \mathrm{TCP}+\mathrm{SVF} \\
\text { Group 3: } \mathrm{BCP} \\
\text { Group 4: } \mathrm{BCP}+\mathrm{SVF}\end{array}$ & $\begin{array}{c}\text { Histology } \\
\text { Histomorphometry }\end{array}$ & $\begin{array}{l}6 \mathrm{mo} \\
\text { All groups: =bone formation, } \\
\text { blood vessels }\end{array}$ & [40] \\
\hline $\begin{array}{l}\text { Clinical trial: } \\
10 \mathrm{pz} \text { ( } 46-69 \text { yrs) edentulous in the } \\
\text { posterior maxilla } \\
\text { Autologous SVF from abdomen } \\
\beta \text { TCP scaffold } \\
\text { BCP (HA/ } \beta \text { TCP } 60 \% / 40 \%) \\
\text { scaffold }\end{array}$ & $\begin{array}{l}\text { Group 1: } \beta \mathrm{TCP} \\
\text { Group 2: } \beta \mathrm{TCP}+\mathrm{SVF} \\
\quad\left(20 \times 10^{6}\right) \\
\text { Group 3: BCP } \\
\text { Group 4: } \mathrm{BCP}+\mathrm{SVF} \\
\quad\left(10 \times 10^{6}\right)\end{array}$ & $\begin{array}{c}\text { Micro-CT } \\
\text { Histomorphometry }\end{array}$ & $\begin{array}{c}6 \text { mo } \\
\text { Groups } 2 \text { and } 4: \uparrow \mathrm{BV} / \mathrm{TV}, \\
\text { OV/TV than groups } 1 \text { and } 3 \\
\geq 36 \text { mo } \\
\text { No adverse effects }\end{array}$ & [41] \\
\hline
\end{tabular}


TABLE 1: Continued.

\begin{tabular}{|c|c|c|c|c|}
\hline Materials & Treatment groups & Evaluations & Results & Ref \\
\hline $\begin{array}{l}\text { Clinical trial: } \\
8 \mathrm{pz}(62-84 \text { yrs) with displaced } \\
\text { low-energy fractures of the } \\
\text { proximal humerus } \\
\text { Autologous SVF from abdomen } \\
\text { Fibrin hydrogel+porous silicate } \\
\text { HA microgranules scaffold } \\
\text { In vivo: } \\
\text { Adult nude rats with a critically } \\
\text { sized segmental defect in femora } \\
(6 \mathrm{~mm}) \\
\text { Fibrin hydrogel+porous silicate } \\
\text { HA microgranules scaffold } \\
\text { hSVF }\left(8 \times 10^{6}\right) \text { from abdomen }\end{array}$ & $\begin{array}{l}\text { Clinical trial: } \\
\text { Group 1: scaffold+SVF } \\
\text { pelleted } \\
\text { In vivo: } \\
\text { Group 1: scaffold } \\
\text { Group 2: scaffold+SVF }\end{array}$ & $\begin{array}{l}\text { Clinical trial: } \\
\text { Safety } \\
\text { Histology } \\
\text { Micro-CT } \\
\text { In vivo: } \\
\text { Micro-CT } \\
\text { Histology }\end{array}$ & $\begin{array}{c}\text { Clinical trial: } \\
12 \text { mo } \\
\text { Group 1: no adverse reactions; } \downarrow \text { pain during } \\
\text { time; } \uparrow \text { formed bone ossicles during time } \\
\text { In vivo: } \\
2 \text { mo } \\
\text { Group 2: } \uparrow \text { mineralized volume, BV/TV, } \\
\text { newly formed bone, frank bone, early stage } \\
\text { of maturation than group } 1\end{array}$ & [42] \\
\hline
\end{tabular}

in muscular pouches of nude mice, showing a high vascular volume in the presence of hSVF up to 6 weeks later [35]. Demineralized bone matrix (DBM) or DBM combined with polylactic acid (PLA), seeded or not with SVF, were always used in critically sized defects, and after 2 months, it was observed that when used alone, both scaffolds increased defect filling, but when combined with SVF, they also increased BA and OCN protein levels [36].

The poly(lactide-co-glycolide) (PLGA) scaffold was seeded with SVF, osteogenically induced or not, and implanted into rabbit ulna defects. Two months after implanting, SVF that was not osteogenically induced increased bone volume fraction (BVF), while SVF that was osteogenically induced also increased defect bridging, trabecular bone, and trabecular thickness (Tb.Th) [37].

In ONJ-like lesions, after 2 and 4 weeks, SVF increased living $\mathrm{BA}$, osteocytes, bone filling, $\mathrm{Tb}$.Th, bone mineral density (BMD), collagen fibers, blood vessels, and F4/80+ macrophages, while it reduced necrotic BA, empty lacunae, trabecular separation (Tb.Sp), and polymorphonuclear (PMN) infiltration in comparison with saline solution [38].

Finally, SVF injection in the carpal bone allowed a horse to return to racing after 4 months with no injuries and lameness and even with a higher performance level after 20 months [39].

3.1.3. Clinical Studies. Three clinical studies were performed in 10 edentulous patients $[40,41]$ and in 8 patients with displaced low-energy fractures of the proximal humerus [42]. SVF was autologous and was obtained from the abdomen $[41,42]$ or nonspecified sites [40] (Table 1).

In two studies, biphasic calcium phosphate (BCP) or $\beta$ TCP scaffolds, with or without SVF, were implanted in edentulous patients $[40,43]$. After 6 months, the first study showed similar bone formation and blood vessels in all treatments [40], while the second study showed higher BV and osteoid volume (OV) when SVF was added to scaffolds in comparison to the same scaffolds alone, with no adverse effects after 3 years [41].

Finally, through the setup of a clinical trial, it was shown that the SVF pellet, mixed with fibrin hydrogel and silicate HA microgranules, reduced pain and increased bone ossicles
1 year after implantation in low-energy fractures of the humerus. In the same study, a previous in vivo study was performed in a critically sized segmental defect of the femora in nude mice, in which porous silicate HA microgranules and hSVF increased mineralized volume, BV, and early stage of maturation, 2 months after implantation [42].

\subsection{SVF and Cartilage}

3.2.1. In Vitro Studies. One in vitro study was performed with hSVF or hADSCs harvested from the abdomen, and with human chondrocytes (Table 2). After 1 month, the addition of hSVF to chondrocyte cultures induced a higher amount of glycosaminoglycans (GAG) and increased cell proliferation than hADSCs cocultured with chondrocytes. In the same study, allogenic chondrocytes combined with allogenic SVF increased GAG and COLL II 2 months after they had been implanted in subcutaneous pouches of nude mice [43].

3.2.2. In Vivo Studies. Three in vivo studies were conducted in goats with osteochondral defects in the trochlea femoris and the medial femoral condyle [44], in sheep with knee OA [7], and in NOD/SCID mice with cartilage injury [45]. SVF was derived from nonspecified sites [44], the cardiothoracic region [7], or the abdomen [45] and was autologous [7, 44] or xenogenic [45] (Table 2).

In the first study, SVF and ADSCs were seeded onto COLL I/COLL III scaffolds and implanted into osteochondral defects. After 4 months, scaffolds with SVF induced higher hyaline cartilage and subchondral bone (SB) regeneration than a scaffold alone or a scaffold combined with ADSCs [44].

In the second study, in the presence of OA, SVF, combined with hyaluronic acid, reduced COLL $\mathrm{X}$ and increased stromal cell-derived factor 1 (SDF1) protein production in comparison to ADSCs or hyaluronic acid alone [7].

In the third study, hSVF mixed with PRP significantly reduced the recovery time (in terms of animal movement) and cartilage lesion area more than phosphate-buffered saline (PBS), 45 days from injection into cartilage injuries [45].

3.2.3. Clinical Studies. Eight clinical studies were performed in patients with OA, full-thickness chondral defect of the 
TABLE 2: In vitro, in vivo, and clinical studies on SVF in cartilage regeneration.

\begin{tabular}{|c|c|c|c|c|}
\hline Experimental model & Treatment groups & Evaluations & Results & Ref. \\
\hline $\begin{array}{l}\text { In vitro: } \\
\text { Human chondrocytes }\left(2 \times 10^{5}\right) \text { from } \\
\text { healthy donors } \\
\text { hSVF or hADSCs }\left(2 \times 10^{5}\right) \text { from } \\
\text { abdomen } \\
\text { In vivo: } \\
10 \text { BALB/C nude mice }(6 \text { wks) with } \\
\text { subcutaneous pouches } \\
\text { Allogenic SVF or ADSCs } \\
\text { Allogenic chondrocytes }\left(1 \times 10^{7}\right)\end{array}$ & $\begin{array}{c}\text { In vitro: } \\
\text { Group 1: SVF pellet } \\
\text { Group 2: ADSC pellet } \\
\text { Group 3: chondrocyte } \\
\text { pellet } \\
\text { Group 4: } \\
\text { SVF+chondrocyte pellet } \\
(4: 1) \\
\text { Group 5: } \\
\text { ADSCs+chondrocyte } \\
\text { pellet }(4: 1) \\
\text { In vivo: } \\
\text { Group 1: no treatment } \\
\text { Group 2: } \\
\text { SVF+chondrocytes }(4: 1) \\
\text { in 2\% alginate } \\
\text { Group 3: } \\
\text { ADSCs+chondrocytes } \\
\text { (4:1) in } 2 \% \text { alginate } \\
\text { Group 4: chondrocytes }\end{array}$ & $\begin{array}{c}\text { In vitro: } \\
\text { Histology } \\
\text { GAG } \\
\text { quantification } \\
\text { Cell proliferation } \\
\text { In vivo: } \\
\text { Histology } \\
\text { GAG } \\
\text { quantification } \\
\text { IHC (COLL II) }\end{array}$ & $\begin{array}{c}\text { In vitro: } \\
1 \text { mo } \\
\text { Group 4: } \uparrow \text { GAG, chondrocytes } \% \text { than } \\
\text { group } 5 \\
\text { In vivo: } \\
2 \text { mo } \\
\text { Group 2: } \uparrow \text { GAG, COLL II protein than } \\
\text { groups } 1,3 \text {, and } 4\end{array}$ & [43] \\
\hline
\end{tabular}

In vivo:

8 skeletally mature Dutch milk goats $(82.4 \pm 11.7 \mathrm{~kg})$ with 2 osteochondral defects in the right troclea femoris and 2 defects in the right medial femoral condyles

Autologous SVF or ADSCs $\left(5 \times 10^{6}\right)$

COLL I/COLL III scaffold $(5 \times 3 \mathrm{~mm})$

\section{$1 \mathrm{mo}$}

Group 1: =gross appearance score, histological score than groups 2 and 3.

Group 1: scaffold Group 2: scaffold+SVF Group 3: scaffold+ADSCs
Gross evaluations Histology Micro-CT $4 \mathrm{mo}$

Group 2: $\uparrow$ cartilage and SB regeneration [44] than groups 1 and 3

Group 2: $\uparrow$ hyaline cartilage; $\downarrow$

fibrocartilage, cartilaginous tissue in SB than group 3

\section{In vivo:}

30 small tail Han sheep (6 mo) with OA in the right knee

Autologous SVF $\left(1 \times 10^{7}\right)$ or ADSCs from cervicothoracic region

HA scaffold (600-1500 kDa) $(2.5 \mathrm{ml})$
Group 1: saline (5 ml)

Group 2: scaffold

Group 3: scaffold+ADSCs

$$
\left(1 \times 10^{7}\right)
$$

Group 4: scaffold+ADSCs

$$
\left(5 \times 10^{7}\right)
$$

\begin{tabular}{|c|c|c|c|}
\hline $\begin{array}{l}\text { In vivo: } \\
9 \text { NOD/SCID mice with injured cartilage } \\
\text { hSVF }\left(2 \times 10^{6}\right) \text { from abdomen }\end{array}$ & $\begin{array}{c}\text { Group 1: PBS } \\
\text { Group 2: SVF+PRP }\end{array}$ & $\begin{array}{l}\text { Movement } \\
\text { recording } \\
\text { Histology } \\
\text { Histomorphometry }\end{array}$ & $\begin{array}{c}45 \text { days } \\
\text { Group 2: } \downarrow \text { time required that mice could } \\
\text { move, cartilage lesion area; } \uparrow \text { formed } \\
\text { neocartilage than group } 1\end{array}$ \\
\hline $\begin{array}{l}\text { Clinical trial: } \\
13 \mathrm{pz}(65-82 \mathrm{yrs}) \text { with bilateral severe OA } \\
\text { Allogenic SVF }\left(3 \times 10^{7}\right) \text { from abdomen }\end{array}$ & Group 1: SVF & Clinical evaluation & $\begin{array}{c}1 \text { and } 6 \text { mo } \\
\text { Group 1: } \downarrow \text { JKOM score, WOMAC score, } \\
\text { VAS score than presurgery. } \\
\text { No differences between } 1 \text { and } 6 \text { mo }\end{array}$ \\
\hline $\begin{array}{l}\text { Clinical trial: } \\
18 \mathrm{pz}(59.6 \pm 10.5 \mathrm{yrs}) \text { with OA } \\
\text { Autologous SVF }(35 \mathrm{ml}) \text { from abdomen }\end{array}$ & Group 1: SVF & $\begin{array}{c}\text { Clinical evaluation } \\
\text { Radiography }\end{array}$ & $\begin{array}{c}3,6 \text {, and } 18 \text { mo } \\
\text { Group 1: } \downarrow \text { VAS score, WOMAC \% than } \\
\text { presurgery. No infection, } \\
\text { thromboembolism, adverse reaction } \\
18 \text { mo } \\
\text { Group } 1:=\text { outerbridge score than } \\
\text { presurgery }\end{array}$ \\
\hline
\end{tabular}

Group 5: scaffold+SVF 
TABLE 2: Continued.

\begin{tabular}{lcc}
\hline Experimental model & Treatment groups & Evaluations \\
\hline & & \\
Clinical trial: & & \\
$10 \mathrm{pz}(\geq 50$ yrs) with idiopathic knee OA & Group 1: SVF+PRP (3 ml) & $\begin{array}{c}\text { Clinical evaluation } \\
\text { SF analysis }\end{array}$ \\
Allogenic SVF (5 ml) from abdomen & &
\end{tabular}

Results
$3,6,12,18$, and 24 mo
roup 1: $\downarrow$ WOMAC total, WOMAC
tiffness, WOMAC pain, WOMAC
distance than presurgery
24 mo

Allogenic SVF $(5 \mathrm{ml})$ from abdomen

SF analysis

Group 1: no atypical cells in SF, restore

SF properties, synovial metabolism; $\downarrow$ cartilage pathology than presurgery

\section{Clinical trial:}

$4 \mathrm{pz}$ (23-74 yrs) with OA of both knees Autologous SVF $\left(5 \times 10^{7}, 6 \times 10^{7}, 7.5 \times\right.$ $10^{7}$, and $10 \times 10^{7}$ ) from periumbilical region

Group 1: SVF+PRP (3 ml)

(4 injections every Clinical evaluation month)
$12 \mathrm{mo}$

Group 1: $\uparrow$ KOOS score pain, symptoms ADL, sport/rec function, knee-related

QOL. Pz regained normal functional activity

\section{$12 \mathrm{mo}$}

Group 2: $\downarrow$ BM edema than group 1

Clinical trial:

$30 \mathrm{pz}$ (>18 yrs) with OA

Autologous SVF from abdomen
Group 1: arthroscopic microfracture
Group 2: arthrosopic microfracture $+\mathrm{SVF}+\mathrm{PRP}$ $(5 \mathrm{ml})$

Clinical evaluation BM edema
Group 1: $\downarrow$ WOMAC score during time $18 \mathrm{mo}$

Group 2: $\downarrow$ WOMAC score during time Group 2: $\downarrow$ WOMAC score; $\uparrow$ Lysholm score than group 1

\section{$12 \mathrm{mo}$}

Groups 1 and 2: $\downarrow$ VAS score, WOMAC score during time 24 mo
$33 \mathrm{pz}$ (>38 yrs) with OA

Autologous SVF (6 ml with 90-120 × $10^{6}$ cells) from abdomen
Clinical trial:
Group 1: arthroscopic microfracture

Group 2: arthroscopic microfracture + SVF
Clinical evaluation

BM edema roup 2: $\downarrow$ VAS score, WOMAC score, Outerbridge score than group 1

Groups 1 and 2: $\uparrow$ Lysholm score during

$\sqrt{2}+2$

\author{
Clinical trial: \\ $16 \mathrm{pz}(53 \pm 10.97 \mathrm{yrs})$ with bilateral OA of \\ grade II or III \\ Hyaluronic acid $(4 \mathrm{ml})$ \\ Autologous SVF (4 ml) from abdomen
}

Group 1: arthroscopic debridement+SVF

Group 2: arthroscopic debridement+HA
Clinical evaluation Radiography time

Group 2: $\downarrow$ BM edema during time Group 1: $\uparrow$ BM edema during time

$$
1,3,6 \text {, and } 12 \text { mo }
$$

Group 1: $\downarrow$ VAS, WOMAC pain, WOMAC stiffness; $\uparrow$ ROM during time

Group 2: $\uparrow$ VAS, WOMAC pain,

WOMAC stiffness; $\downarrow$ ROM than group 1 $1 \mathrm{mo}$

Group 2: $\uparrow$ ROM during time

$$
3,6 \text {, and } 12 \text { mo }
$$

Group 2: $\downarrow$ ROM during time 1 and 3 mo

Group 2: $\downarrow$ VAS during time 6 and $12 \mathrm{mo}$

Group 2: $\uparrow$ VAS during time

Group 1: $\uparrow$ MOCART score during time

Group 1: $\uparrow$ MOCART score, complete

tissue filling than group 2

Group 2: $\downarrow$ MOCART score during time

\section{6-25 mo}

\section{Clinical trial:}

$26 \mathrm{pz}(46.1 \pm 12.2 \mathrm{yrs})$ with full-thickness chondral defect of the talar dome Autologous SVF $\left(3.94 \times 10^{6}\right.$ MSCs $)$ from buttock
Group 1: arthroscopic marrow stimulation Group 2: arthroscopic marrow stimulation+SVF
Clinical evaluation Radiography
Groups 1 and 2: $\downarrow$ VAS score; $\uparrow$ AOFAS score during time

Group 2: $\downarrow$ VAS score; $\uparrow$ AOFAS score, Tegner score, MOCART score than group 2 
TABLe 2: Continued.

\begin{tabular}{|c|c|c|c|c|}
\hline Experimental model & Treatment groups & Evaluations & Results & Ref. \\
\hline $\begin{array}{l}\text { Clinical trial: } \\
1 \mathrm{pz}(36 \text { yrs) with traumatic } \\
\text { osteochondral lesion of the right medial } \\
\text { femoral condyle } 8 \text { mo after injury } \\
\text { Autologous SVF }\left(1.5 \times 10^{6}\right) \text { from } \\
\text { abdomen }\end{array}$ & $\begin{array}{c}\text { Group 1: } \\
\text { microfracture+SVF }\end{array}$ & $\begin{array}{c}\text { Clinical evaluation } \\
\text { BM edema } \\
\text { Radiography }\end{array}$ & $\begin{array}{c}24 \text { mo } \\
\text { Group 1: } \uparrow \text { IKDC, EQ-VAS than } \\
\text { presurgery } \\
12 \text { and } 24 \text { mo } \\
\text { Group 1: recovery of CT; } \downarrow \text { BM edema } \\
\text { than presurgery }\end{array}$ & [54] \\
\hline
\end{tabular}

talar dome [50], and traumatic osteochondral defect of the right femoral condyle [54].

Allogenic or autologous SVF was obtained from the abdomen [42-44, 46-48, 50], periumbilical region [45], and buttocks [49] (Table 2).

In patients with $\mathrm{OA}$, the treatments consisted of SVF alone [46, 47]; SVF and PRP [48, 49]; SVF, PRP, and arthroscopic microfracture [50, 51]; or SVF and arthroscopic debridement [52].

The injection of SVF alone reduced changes in Japanese Knee Osteoarthritis Measure (JKOM), Western Ontario and McMaster Universities Osteoarthritis Index (WOMAC), and visual analog scale (VAS) scores after 1, 3, 6, and 18 months $[46,47]$ with no infection, thromboembolism, or adverse reactions [47]. The combination of SVF and PRP reduced WOMAC scores and increased the six-minute distance parameter after 3 months, 6 months, 1 year, and 2 years [48] and ameliorated Knee injury and Osteoarthritis Outcome Score (KOOS), symptoms, and functional activity at 1 year [49]. Arthroscopic microfracture was accompanied with SVF injection with or without PRP. With the addition of PRP, bone marrow edema and WOMAC score was reduced and Lysholm score was increased after 12 and 18 months [50], while without PRP, bone marrow edema, VAS, WOMAC, and Outerbridge scores were reduced after 12 and 24 months [51]. In one study, in which OA was treated with arthroscopic debridement, the addition of SVF reduced VAS and WOMAC scores and increased the range of motion (ROM) more than hyaluronic acid at 1, 3, 6, and 12 months, while it increased the Magnetic Resonance Observation of Cartilage Repair (MOCART) score and complete tissue filling more than hyaluronic acid at 6 and 12 months [52].

Regarding the full-thickness chondral defect, SVF, associated with arthroscopic marrow stimulation, reduced the VAS score and increased the American Orthopedic Foot and Ankle Score (AOFAS) and the Tegner and MOCART scores more than the technique alone after 25 months [53].

In a traumatic osteochondral lesion, microfracture associated with SVF and fibrin sealant increased the International Knee Documentation Committee (IKDC) score, the EuroQol-visual analog scale (EQ-VAS) score, and the recovery of the cartilage thickness and reduced bone edema after 1 and 2 years [54].

\subsection{SVF and Tendon}

3.3.1. In Vivo Studies. Four in vivo studies were performed in rabbits [55-58] with transection of the midsubstance of the deep digital flexor (DDF) tendon [55], transection of the cen- tral one third of the flexor tendon [56], or with the supraspinatus tendon severed from the great trochanter $[57,58]$. SVF was harvested from the inguinal region and was allogenic [55, 56] or autologous [57, 58] (Table 3).

SVF was injected in the complete transection of the DDF tendon, and after 2 months, fibrillar linearity and continuity, COLL I production, ultimate load, energy absorption, and stiffness increased, while the number of capillaries and COLL III production decreased [55].

SVF and BMSCs, injected in the complete transection of the flexor tendon, increased energy absorption, ultimate load, ultimate stress, yield load, and stiffness after 3 and 8 weeks [56].

After 1, 2, and 3 months from SVF injection into the supraspinatus tendon severed from the great trochanter, maximum load, maximum strength, stiffness, and signal-tonoise quotient (SNQ) increased [57], as well as tendonbone healing, COLL I, and bone morphogenetic protein 2 (BMP2) after 2 months [58].

3.3.2. Clinical Studies. The two clinical studies were performed. One study included 45 patients with noninsertional Achilles tendinopathy (NIAT) [59], and the other study included 44 patients with chronic tendinopathy of the Achilles tendon [60]. SVF was allogenic and harvested from the abdomen $[59,60]$ (Table 3).

In the first study, both PRP and SVF reduced VAS and increased MR size, US size, and peri- and intratendinous flow (PD), while only SVF increased MR signal intensity (MR-Si) after 6 months [59].

Similarly, PRP and SVF were compared in Achilles tendon tendinopathy. Both PRP and SVF reduced VAS and increased the Victorian Institute of Sports Assessment-Achilles (VISA-A) questionnaire score, AOFAS score, and SF-36 score after 2 weeks, 1, 2, 4, and 6 months, showing better results with SVF [60].

\subsection{AECs and Bone}

3.4.1. In Vitro Studies. Four in vitro studies were conducted with human AECs (hAECs) [61-64] (Table 4).

In the first study, hAECs and hADSCs were compared in terms of osteogenic and chondrogenic differentiation. After 3,7 , and 14 days of culture, hAECs showed higher RUNX2 and SOX9 gene expression, OCN, aggrecan, and COLL II protein than hADSCs. After 14 and 28 days, mineralization was more pronounced in hAECs than in hADSCs [61].

Keeping in terms of osteogenic differentiation, hAECs, cultured in $\mathrm{OM}$ and stimulated with pulsed electromagnetic 
TABLE 3: In vitro, in vivo, and clinical studies on SVF in tendon regeneration.

\begin{tabular}{|c|c|c|c|c|}
\hline Experimental model & Treatment groups & Evaluations & Results & Ref \\
\hline $\begin{array}{l}\text { In vivo: } \\
20 \text { adult NZW rabbits }(2.5-3 \mathrm{~kg}) \\
\text { with complete transaction of } \\
\text { DDFT midsubstance } \\
\text { Allogenic SVF }\left(4 \times 10^{6}\right) \text { from } \\
\text { inguinal region }\end{array}$ & $\begin{array}{c}\text { Group 1: PBS }(0.2 \mathrm{ml}) \\
\text { Group 2: SVF }\end{array}$ & $\begin{array}{c}\text { Histology } \\
\text { Histomorphometry } \\
\text { IHC (COLL I, COLL III) } \\
\text { Biomechanics }\end{array}$ & $\begin{array}{l}2 \text { mo } \\
\text { Group 2: } \uparrow \text { fibrillar linearity, fibrillar } \\
\text { continuity, COLL I protein, ultimate } \\
\text { load, energy absorption, stiffness; } \\
\downarrow \text { no. of capillaries in neotendon, } \\
\text { COLL III protein than group } 1\end{array}$ & [55] \\
\hline
\end{tabular}

In vivo:

36 adult NZW rabbits $(2.5-3 \mathrm{~kg})$ with a complete transaction through the central one third of flexor tendon Allogenic SVF $\left(4 \times 10^{6}\right)$ from inguinal region

Allogenic BMSCs $\left(4 \times 10^{6}\right)$ from iliac crest

Group 1: PBS (0.2 ml)

Group 2: SVF

Group 3: BMSCs
3 and 8 wks

Biomechanics Groups 2 and 3: $\uparrow$ energy absorption, ultimate load, ultimate stress, yield load, stiffness than group 1
In vivo:

36 adult NZW rabbits $(2-2.5 \mathrm{~kg})$ with supraspinatus tendon severed from the great trochanter

Autologous SVF from inguinal region

\author{
Group 1: FG (1 ml) \\ Group 2: SVF+FG \\ $(1 \mathrm{ml})$
}

\section{$1 \mathrm{mo}$}

Group 2: $\uparrow$ maximum load, maximum strength than group 1

2 mo

Radiography

Biomechanics

Group 2: $\uparrow$ maximum load, maximum strength, stiffness than group 1 3 mo

Group 2: $\uparrow$ SNQ, stiffness than group 1

In vivo:

36 NZW rabbits $(2-2.5 \mathrm{~kg})$ with bilateral supraspinatus tendon severed from the great trochanter

Autologous SVF from inguinal region
Group 1: FG $(1 \mathrm{ml})$

Group 2: SVF+FG $(1 \mathrm{ml})$
$2 \mathrm{mo}$
Histology

IHC (COLL I,

COLL III, BMP2)

Histomorphometry

Biomechanics
Group 2: $\uparrow$ tendon-bone healing maturity, COLL I, COLL III, COLL I/COLL III, BMP2 protein, maximum load, maximum strength, stiffness [58] than group 1

$6 \mathrm{mo}$

Radiography Clinical evaluation
Clinical trial:

$43 \mathrm{pz}$ (29-55 yrs) with unilateral or bilateral NIAT

Allogenic SVF (4 ml) from abdomen
Group 1: PRP (4 ml) Group 2: SVF
Groups 1 and 2: $\downarrow$ VAS; $\uparrow$ MR size,

US size, PD than presurgery Group 1: $\downarrow$ MR-Si than group 2

2 wks, $1 \mathrm{mo}, 4 \mathrm{mo}$, and $6 \mathrm{mo}$ Groups 1 and 2: $\downarrow$ VAS pain scale;

$\uparrow$ VISA-A score, AOFAS score, SF-36

Group 1: PRP (4 ml) Group 2: SVF
Clinical evaluation
$44 \mathrm{pz}$ (18-55 yrs) with unilateral or bilateral chronic tendinopathy of the Achilles tendon

Allogenic SVF (4 ml) from abdomen than presurgery 2 wks

Group 2: $\downarrow$ VAS pain scale; $\uparrow$ VISA-A score, AOFAS score than group 1 $1 \mathrm{mo}$

Group 2: $\downarrow$ VAS pain scale than group fields (PEMFs), increased ALP, BMP2, RUNX2, nuclear factor erythroid 2-related factor 2 (NRF2), Kelch-like ECH-associated protein 1 (KEAP1) and OCN gene expression, ALP activity, and OCN protein and calcium deposition in comparison to cells in NM or in OM, without PEMFs, after 3, 7, 11, and 21 days. The addition of PEMFs in NM also induced ALP and OCN gene expression, ALP activity, and OCN protein and calcium deposition, after $3,7,11$, and 21 days [62].

The effect of conditioned medium from hAECs, produced after 24 hours of culture, on human fetal osteoblast cell line (hFOB1.19) was evaluated in one study. Conditioned medium increased hFOB1.19 cell migration and prolifera- tion; ALP activity; and ALP, OCN, OPN, and RUNX2 gene expression after 2 hours and 1,2,3, and 6 days. The addition of the antibody against transforming growth factor $\beta$ (TGF $\beta 1$ ) in the culture medium reduced ALP activity, ALP and OCN gene expression, and cell migration after 6 hours and 6 days [63].

Finally, a study showed how mechanical stretch (with a maximum uniaxial stretched length of $7.35 \mathrm{~cm}, 5 \%$ of elongation, and frequency of $0.5 \mathrm{~Hz}$ ) increased OCN, RUNX2, ALP, $\beta$-catenin, and Cyclin D1 gene expression and protein expression 6,12 , and $24 \mathrm{hrs}$ after stimulation, with a synergic effect when OM was added [64]. 
TABLE 4: In vitro, in vivo, and clinical studies on AECs in bone regeneration.

\begin{tabular}{|c|c|c|c|c|}
\hline Experimental model & Treatment groups & Evaluations & Results & Ref \\
\hline $\begin{array}{l}\text { In vitro: } \\
\text { hAECs } \\
\text { Purchased hADSCs }\end{array}$ & $\begin{array}{c}\text { Group 1: hAECs }\left(2.1 \times 10^{4}\right) \text { cultured in OM } \\
\text { Group 2: hADSCs }\left(2.1 \times 10^{4}\right) \text { cultured in OM } \\
\text { Group 3: hAECs }\left(1 \times 10^{5} \text { per pellet }\right) \text { cultured } \\
\text { in CM } \\
\text { Group 4: hADSCs }\left(1 \times 10^{5} \text { per pellet }\right) \text { cultured } \\
\text { in CM }\end{array}$ & $\begin{array}{l}\text { RT-PCR (RUNX2, } \\
\text { SOX9) } \\
\text { Alizarin red staining } \\
\text { Alcian blue staining } \\
\text { IHC (OCN, AGG, } \\
\text { and COLL II) }\end{array}$ & $\begin{array}{c}\text { 3, 7, and } 14 \text { days } \\
\text { Group } 1: \uparrow \text { RUNX2 gene } \\
\text { expression, OCN protein than } \\
\text { group } 2 \\
\text { Group } 3: \uparrow \text { AGG and COLL II } \\
\text { proteins, SOX9 gene } \\
\text { expression, than group } 4 \\
2 \text { and } 4 \text { wks } \\
\text { Group } 1: \uparrow \text { mineralization } \\
\text { during time }\end{array}$ & [61] \\
\hline
\end{tabular}

3,7 , and 11 days

Group 4: $\uparrow$ ALP, OCN gene

expression than groups 1-3

Group 3: $\uparrow$ ALP, OCN than

groups 1 and 2

Group 2: $\uparrow$ ALP, OCN than group 1 7 days

Group 3: $\uparrow$ ALP activity,

In vitro:

hAECs

$\mathrm{PEMF}=50 \mathrm{~Hz}, 1 \mathrm{mT}$ for

30 min each time, 2 for days with an interval of 12 hours
Group 1: hAECs in NM

Group 2: hAECs in OM Group 3: hAECs in NM+PEMF Group 4: hAECs in OM+PEMF
RT-PCR (ALP, OCN, BMP2, RUNX2, NRF2, and KEAP1) ALP activity IHC (OCN) Calcium deposition calcium deposition than group

$$
7,11 \text {, and } 21 \text { days }
$$

Group 2: $\uparrow$ ALP activity than groups 1 and 3

Group 4: $\uparrow$ ALP activity, OCN protein, calcium deposition than groups 1-3

Group 3: $\uparrow$ OCN protein than group 1 21 days

Group 2: $\uparrow$ OCN protein, calcium deposition than groups 1 and 3

3, 11, and 21 days Group 4: $\uparrow$ BMP2, RUNX2, NRF2, and KEAP1 gene expression than groups 1-3

$$
2 \mathrm{hrs}
$$

Group 2: $\uparrow$ hFOB1.19 migration than group 1

$$
1,2 \text {, and } 3 \text { days }
$$

Group 2: $\uparrow$ hFOB1.19 proliferation than group 1

Cell proliferation Cell migration ALP activity RT-PCR (ALP, OCN, OPN, and RUNX2)
In vitro:

Conditioned medium from hAECs after 24 hrs of culture Purchased hFOB1.19 $\left(5 \times 10^{3}\right)$
Group 1: hFOB1.19 in NM

Group 2: hFOB1.19 in conditioned medium Group 3: hFOB1.19 in conditioned medium+TGF $\beta 1$ antibody $(5 \mu \mathrm{g} / \mathrm{ml})$

$$
6 \text { days }
$$

Group 2: $\uparrow$ hFOB1.19 ALP activity, ALP, OCN, OPN,

RUNX2 gene expression than

$$
\text { group } 1
$$

Group 3: $\downarrow$ hFOB1.19 ALP activity, ALP, OCN gene expression than group 2 $6 \mathrm{hrs}$

Group 3: $\downarrow$ hFOB1.19

migration than group 2 
TABle 4: Continued.

\begin{tabular}{|c|c|c|c|c|}
\hline Experimental model & Treatment groups & Evaluations & Results & Ref \\
\hline $\begin{array}{l}\text { In vitro: } \\
\text { hAECs (3rd-5th passage) } \\
\text { from } 6 \text { patients ( } 32 \pm 4.5 \mathrm{yrs})\end{array}$ & $\begin{array}{c}\text { Group 1: hAECs in NM } \\
\text { Group 2: hAECs+mechanical stretch } \\
\text { (maximum uniaxial stretched length }(7.35 \mathrm{~cm} \text { ) } \\
\text { for 2, 6, 12, and } 24 \text { hrs with } 5 \% \text { elongation at a } \\
\text { frequency of } 0.5 \mathrm{~Hz} \\
\text { Group 3: hAECs in OM for } 21 \text { days } \\
\text { Group 4: hAECs+OM for } 21 \text { days+mechanical } \\
\text { stretch for 2, 6, 12, and } 24 \text { hrs } \\
\text { Group 5: hAECs+Runx2 shRNA+OM for } \\
24 \text { hrs } \\
\text { Group 6: hAECs+Runx2 shRNA+mechanical } \\
\text { stretch for } 24 \text { hrs } \\
\text { Group 7: hAECs+Runx2 } \\
\text { shRNA+OM+mechanical stretch for } 24 \text { hrs }\end{array}$ & $\begin{array}{c}\text { RT-PCR (ALP, } \\
\text { OCN, RUNX2, } \beta \text { - } \\
\text { catenin, and Cyclin } \\
\text { D1) } \\
\text { WB (ALP, OCN, } \\
\text { RUNX2, } \beta \text {-catenin, } \\
\text { and Cyclin D1) }\end{array}$ & $\begin{array}{c}12 \mathrm{hrs} \\
\text { Groups } 3 \text { and } 4: \uparrow \text { OCN } \\
\text { protein than group } 1 \\
\text { 6, } 12 \text {, and } 24 \text { hrs } \\
\text { Group 3: } \uparrow \text { RUNX2, ALP, and } \\
\text { OCN gene expression than } \\
\text { group 1 } \\
6 \text { and } 12 \text { hrs } \\
\text { Group 4: } \uparrow \text { RUNX2, ALP, } \\
\text { OCN gene expression and } \\
\text { protein than groups } 2 \text { and } 3 \\
\text { 12 hrs } \\
\text { Group 3: } \uparrow \beta \text {-catenin, RUNX2, } \\
\text { Cyclin D1 gene expression and } \\
\text { protein than group } 1 \\
\text { Group 4: } \uparrow \beta \text {-catenin, RUNX2, } \\
\text { Cyclin D1 gene expression and } \\
\text { protein than groups } 2 \text { and } 3 \\
24 \text { hrs } \\
\text { Groups 5-7: } \downarrow \text { RUNX2, OCN } \\
\text { gene expression, and protein } \\
\text { than groups 2-4 }\end{array}$ & [64] \\
\hline
\end{tabular}

In vivo:

6 adult sheep ( 2 yrs) that

need bilateral sinus

augmentation
Allogenic oAECs $\left(1 \times 10^{6}\right)$

from 3 slaughtered sheep

Group 1: scaffold

Group 2: scaffold+AECs

( 3 mo of pregnancy)

CaP (HA- $\beta$ TCP: 30/60) scaffold

$\begin{array}{ccc} & & 45 \text { days } \\ \text { Group 1: scaffold } & \text { Micro-CT } & \text { Group 2: } \uparrow \text { VEGF, VA; } \uparrow \text { BA } \\ \text { Group 2: scaffold+AECs } & \text { than group } 1 \\ & \text { Histology } & 3 \text { mo } \\ & \text { IHC (VEGF) } & \text { Group 2: } \downarrow \text { VEGF, VA; } \uparrow \text { BA } \\ & \text { than group } 1\end{array}$

45 days

In vivo:

$16 \mathrm{SD}$ rats (7 wks) with

unilateral maxillary alveolar

defect

hAECs

$\beta$ TCP scaffold $(4 \times 3 \times 3 \mathrm{~mm}$

Group 1: scaffold

Group 2: scaffold+AECs

Micro-CT

Histology

Histomorphometry

IHC (CD68, VEGF)

Group 2: $\downarrow$ Tb.Sp, CD68 than group 1

$2 \mathrm{mo}$

Group 2: $\uparrow \mathrm{BMD}, \mathrm{BV} / \mathrm{TV}$,

Tb.N, BA, VEGF area, CD68 than group 1
In vivo:

3 nude mice with

subcutaneous pouches

hAECs, hBMSCs, hAFMSCs

$\beta$ TCP scaffold $(5 \times 10 \mathrm{~mm})$
Group 1: scaffold

Group 2: scaffold+hAEC

Group 3: scaffold+hBMSCs

Group 4: scaffold+hAFMSCs
$1 \mathrm{mo}$

All groups: no wellmineralized islands

Groups 2-4: viable cells; $\uparrow$

OPN, OCN proteins than group 1
3.4.2. In Vivo Studies. Three studies were conducted in sheep submitted to sinus augmentation [65], in rats with maxillary alveolar defect [66], and in subcutaneous pouches of nude mice [67]. AECs were allogenic [65] or xenogenic [66, 67] (Table 4).

Ovine AECs, seeded onto a calcium phosphate $(\mathrm{CaP})$ scaffold and implanted into alveolar defects, increased vascular endothelial growth factor (VEGF), vascular area, and new bone more than the scaffold alone after 3 months [65]. Similarly, a $\beta$ TCP scaffold, seeded with hAECs, reduced Tb.Sp and CD68 cells and increased BMD, BV, trabecular number (Tb.N), BA, and VEGF more than the scaffold alone after 1 and 2 months [66].
Three types of cells, namely, hAECs, hBMSCs, and hAFMSCs, were seeded onto the $\beta$ TCP scaffold and implanted into subcutaneous pouches, showing higher viable cells and higher OPN and OCN protein production than the scaffold alone, regardless of cells, after 1 month [67].

\subsection{AECs and Cartilage}

3.5.1. In Vitro Studies. There were two in vitro studies conducted with hAECs $[68,69]$ (Table 5).

In the first study, cartilage samples, with a defect of $2 \mathrm{~mm}$, were ex vivo treated with a human amniotic membrane 
TABLE 5: In vitro, in vivo, and clinical studies on AECs in cartilage regeneration.

\begin{tabular}{|c|c|c|c|c|}
\hline Experimental model & Treatment groups & Evaluations & Results & Ref \\
\hline $\begin{array}{l}\text { In vitro: } \\
\text { Cartilage samples with defect of } \\
2 \mathrm{~mm} \\
\text { Human chondrocytes from } \\
\text { femoral heads or knee }\left(1 \times 10^{6}\right) \\
\text { hBMSCs from femoral heads of } \\
\text { donors ( } 50-70 \text { yrs) } \\
\text { hAECs } \\
\text { hAMSC } \\
\text { HAM scaffold }\end{array}$ & $\begin{array}{l}\text { Group 1: scaffold seeded with } \\
\text { chondrocytes+chondrocyte pellet } \\
\qquad\left(6 \times 10^{5}\right) \\
\text { Group 2: scaffold seeded with } \\
\text { BMSCs+BMSC pellet }\left(6 \times 10^{5}\right) \\
\text { Group 3: scaffold seeded with } \\
\text { AECs+AEC pellet }\left(6 \times 10^{5}\right) \\
\text { Group 4: scaffold seeded with } \\
\text { AMSCs+AMSC pellet }\left(6 \times 10^{5}\right)\end{array}$ & $\begin{array}{l}\text { Histology } \\
\text { IHC (COLL I, } \\
\text { COLL II) }\end{array}$ & $\begin{array}{c}2 \text { mo } \\
\text { Group 1: =repair of lesioned area, } \\
\text { ICRS score than groups } 2,3 \text {, and } 4 \\
\text { Group 4: } \uparrow \text { COLL II protein than } \\
\text { group } 1 \\
\text { Group 2: } \uparrow \text { COLL I protein than } \\
\text { groups } 1,3 \text {, and } 4\end{array}$ & [68] \\
\hline $\begin{array}{l}\text { In vitro: } \\
\text { hAECs in micromasses }\left(1 \times 10^{7}\right)\end{array}$ & $\begin{array}{c}\text { Group 1: micromasses+TGF } \beta 1 \\
(1 \mathrm{ng} / \mathrm{ml}) \\
\text { Group 2: } \\
(100 \mathrm{ng} / \mathrm{ml})\end{array}$ & $\begin{array}{l}\text { RT-PCR (SOX9, } \\
\text { COLL II, PG) }\end{array}$ & $\begin{array}{c}3 \text { days } \\
\text { Group 2: } \uparrow \text { SOX9, COLL II gene } \\
\text { expression than group } 1 \\
3 \text { wks } \\
\text { Group 1: } \uparrow \text { SOX9, COLL II gene } \\
\text { expression than group } 2 \\
\text { Groups } 1 \text { and } 2: \uparrow \text { PG gene expression } \\
\text { during time }\end{array}$ & [69] \\
\hline
\end{tabular}

(HAM) scaffold seeded with human chondrocytes, hBMSCs, hAECs, or hAMSCs and added with the respective cell pellets. After 2 months of culture, all treatments showed the same degree of repair and International Cartilage Repair Society (ICRS) score [68].

In the second study, micromasses of hAECs were cultured with TGF $\beta 1$ or BMP7 for 3 days and 3 weeks. The addition of BMP7 increased SOX9 and COLL II gene expression at 3 days, while TGF $\beta 1$ increased it to 3 weeks. Both treatments increased proteoglycan gene expression during time [69].

\subsection{AECs and Tendon}

3.6.1. In Vitro Studies. One in vitro study was conducted with ovine AECs alone or cocultured with fetal or adult ovine tenocytes or tendons (Table 6). After 7, 14, and 28 days of culture, fetal tendons increased AEC migration, while adult tenocytes or tendons reduced AEC proliferation. Fetal tenocytes or tendons increased AEC proliferation and OCN, tenomodulin (TNMD), and scleraxis (SCX) protein production. In addition, fetal tendons reduced the telomere area (TEA) and feret maximum (TEF) and mean densitometric (MEAND) values, while adult tendons or tenocytes reduced COLL III gene expression and TNMD protein [70].

3.6.2. In Vivo Studies. Six in vivo studies were conducted in horses [71, 72] with monolateral acute superficial digital flexor tendon (SDFT) injuries [71] and acute or chronic SDFT injury in the midmetacarpal region [72] or in sheep [73-76] with a bilateral full-thickness hole of flexor digitorum superficialis tendon (FDST) $[73,75]$ or bilateral defect of the middle portion of the Achilles tendon [74, 76]. AECs were xenogenic $[71,72,76]$ or allogenic [73-75] (Table 6).

A reduction in COLL III and an increase in COLL I and Ki-67 proteins after 2 months from ovine AEC injection into SDFT injuries were observed [71].
Ovine AECs induced a cross-sectional area similar to the healthy tendon, parallel collagen fibers, and no vascularization in SDFT tendinopathy after 6 months [72].

Ovine AECs, injected into the hole of FDST, induced greater improvement in tendon microarchitecture, proliferation index, COLL I gene expression, maximum failure load, and stiffness, as well as greater reduction in vascular area (VA); leukocyte infiltration; macrophage infiltration; and CD86, IL12b, and COLL III gene expression than fibrin glue (FG) after 7, 14, and 28 days [73, 75].

Finally, 1 month after ovine AEC injection, an increase in collagen fibers and no inflammation were observed in defects of the Achilles tendon [74], with a rapid recovery; higher biomechanics; higher TNMD, THBS4, CD206, and IL10 gene expression; and lower CD86 and IL12b gene expression in comparison to FG [76].

\section{Discussion}

Treatments for the regeneration of musculoskeletal tissue disorders of bone, cartilage, and tendon could be conservative or surgical. Rehabilitation, anti-inflammatory drugs, biophysical therapy, platelet derivatives (i.e., PRP) or cell therapy [1,77], microfracture, arthroscopy [1], and the implantation of grafts or scaffolds or hydrogels [78] are the main treatment options alone or in combination. Moreover, due to the lesion type and site or the patient characteristics (i.e., age, comorbidities, and lifestyles), some treatments reportedly do not have the ability to regenerate the original healthy tissue or have a short-term or incomplete effect.

Preclinical research has always been focused on finding increasingly innovative and less invasive therapies. In this regard, MSCs, in particular ADSCs and BMSCs, but also MABs and FAPs, have been used in musculoskeletal tissue regeneration, even if they show some limitations: the necessity of two surgical steps (one for the harvesting and one for the implantation after in vitro expansion), patient 
TABLE 6: In vitro, in vivo, and clinical studies on AECs in tendon regeneration.

\begin{tabular}{|c|c|c|c|c|}
\hline Experimental model & $\begin{array}{l}\text { Treatment } \\
\text { groups }\end{array}$ & Evaluations & Results & Ref \\
\hline $\begin{array}{l}\text { In vitro: } \\
\text { oAECs }\left(1 \times 10^{4}\right) \\
\text { Tenocytes }\left(1 \times 10^{4}\right) \text { or tendons } \\
\text { from heel of adult sheep }(2-3 \text { yrs }) \\
\text { or fetus sheep }(2-3 \text { mo })\end{array}$ & $\begin{array}{c}\text { Group 1: } \\
\text { AECs } \\
\text { Group 2: } \\
\text { AECs+fetal } \\
\text { tenocytes } \\
\text { Group 3: } \\
\text { AECs+adult } \\
\text { tenocytes } \\
\text { Group 4: } \\
\text { AECs+fetal } \\
\text { tendons } \\
\text { Group 5: } \\
\text { AECs+adult } \\
\text { tendons }\end{array}$ & $\begin{array}{c}\text { AEC proliferation } \\
\text { AEC migration } \\
\text { AEC telomere analysis } \\
\text { RT-PCR (COLL I, COLL III) } \\
\text { IHC (OCN, TNMD, and } \\
\text { SCXB) }\end{array}$ & $\begin{array}{c}7 \text { days } \\
\text { Group 4: } \uparrow \text { AEC migration than group } 1 \\
2 \text { wks } \\
\text { Groups } 3 \text { and 5: } \downarrow \text { AEC proliferation than group } 1 \\
1 \text { mo } \\
\text { Groups } 2 \text { and } 4: \uparrow \text { AEC proliferation, OCN, } \\
\text { TNMD, and SCXB proteins than group } 1 \\
\text { Group 4: } \downarrow \text { TEA, TEF, and MEAND than group } 1 \\
\text { Groups 2-5: } \uparrow \text { COLL I gene expression than group } \\
1 \\
\text { Group 3: } \downarrow \text { COLL III gene expression than group } 1 \\
\text { Groups } 3 \text { and 5: } \downarrow \text { TNMD protein than group } 1\end{array}$ & [70] \\
\hline $\begin{array}{l}\text { In vivo: } \\
15 \text { horses with acute SDFT } \\
\text { monolateral injuries } \\
\text { oAECs }\left(7 \times 10^{6}\right) \text { from slaughtered } \\
\text { sheep at } 3 \text { mo of pregnancy }\end{array}$ & $\begin{array}{l}\text { Group 1: } \\
\text { healthy } \\
\text { tendons } \\
\text { Group 2: } \\
\text { AECs }\end{array}$ & $\begin{array}{l}\text { Histology } \\
\text { IHC (COLL III, COLL I, and } \\
\text { Ki-67) }\end{array}$ & $\begin{array}{c}2 \text { mo } \\
\text { Group 2: } \downarrow \text { COLL III protein; } \uparrow \text { COLL I, Ki-67 } \\
\text { proteins than group 1, no immunological reaction }\end{array}$ & {$[71]$} \\
\hline $\begin{array}{l}\text { In vivo: } \\
6 \text { adult horses }(3-7 \text { yrs }) \text { with acute } \\
\text { or chronic SDFT tendinopathy in } \\
\text { the midmetacarpal region; } \\
\text { oAECs }\left(7 \times 10^{6}\right) \text { from slaughtered } \\
\text { sheep at } 3 \text { months of pregnancy }\end{array}$ & $\begin{array}{l}\text { Group 1: } \\
\text { AECs }\end{array}$ & $\begin{array}{c}\text { Ultrasonography } \\
\text { Histology }\end{array}$ & $\begin{array}{l}\text { Group 1: cross-sectional area similar to an healthy } \\
\text { tendon, collagen fibers parallel to the longitudinal } \\
\text { axis of the tendon, no neovascularization than } \\
\text { presurgery }\end{array}$ & {$[72]$} \\
\hline $\begin{array}{l}\text { In vivo: } \\
23 \text { sheep }(40 \mathrm{~kg}) \text { with a bilateral } \\
\text { full-thickness FDST hole }(3 \mathrm{~mm} \\
\text { diameter) } \\
\text { Allogenic oAECs }\left(4 \times 10^{6}\right) \text { from } \\
\text { slaughtered sheep at } 3 \text { months of } \\
\text { pregnancy }\end{array}$ & $\begin{array}{l}\text { Group 1: FG } \\
\text { Group 2: } \\
\text { AECs+FG }\end{array}$ & $\begin{array}{c}\text { Histology } \\
\text { RT-PCR (COLL I, COLL III) } \\
\text { Histomorphometry } \\
\text { Biomechanics }\end{array}$ & $\begin{array}{l}2 \text { wks } \\
\text { Group 2: } \uparrow \text { tendon microarchitecture than group } 1 \\
\qquad 1 \text { mo } \\
\text { Group 2: } \uparrow \text { tendon microarchitecture, } \\
\text { proliferation, COLL I gene expression, maximum } \\
\text { failure load, stiffness; } \downarrow \text { VA, leukocyte infiltration, } \\
\text { cellularity, COLL III gene expression than group } 1\end{array}$ & {$[73]$} \\
\hline $\begin{array}{l}\text { In vivo: } \\
3 \text { adult sheep }(50 \mathrm{~kg}) \text { with bilateral } \\
\text { defect in the Achilles tendon } \\
\text { middle portion } \\
\text { Allogenic oAECs }\left(2 \times 10^{6}\right) \text { from } \\
\text { slaughtered sheep at } 60-80 \text { days of } \\
\text { pregnancy }\end{array}$ & $\begin{array}{l}\text { Group 1: no } \\
\text { treatment } \\
\text { Group 2: } \\
\text { AECs }\end{array}$ & Histology & $\begin{array}{l}1 \mathrm{mo} \\
\text { Group 2: absent inflammation-proliferating cells, } \\
\text { collagen fibers started to be oriented along a } \\
\text { longitudinal axis } \\
\text { Group 1: no tendon healing, no proliferating cells, } \\
\text { nonorganized collagen fibers }\end{array}$ & [74] \\
\hline $\begin{array}{l}\text { In vivo: } \\
18 \text { Appenninica breed sheep } \\
\text { ( } 2 \text { yrs) with a full-thickness hole in } \\
\text { FDST }(3 \mathrm{~mm} \text { diameter }) \\
\text { Allogenic oAECs }\left(4 \times 10^{6}\right)\end{array}$ & $\begin{array}{l}\text { Group 1: FG } \\
\text { Group 2: } \\
\text { FG+oAECs }\end{array}$ & $\begin{array}{l}\text { Histology } \\
\text { IHC (COLL I, CD45, CD68, } \\
\text { CD86, and MMR/CD206) } \\
\text { RT-PCR (CD86, CD206, } \\
\text { YM1, IL10, and IL12b) }\end{array}$ & $\begin{array}{c}7,14 \text {, and } 28 \text { days } \\
\text { Group 2: } \uparrow \text { tissue organization; } \downarrow \text { leukocyte } \\
\text { infiltration, IL12 b gene expression than group } 1 \\
14 \text { and } 28 \text { days } \\
\text { Group 2: } \downarrow \text { macrophage infiltration, CD86 gene } \\
\text { expression, CD86 positive cells; } \uparrow \text { IL10 gene } \\
\text { expression than group } 1 \\
28 \text { days } \\
\text { Group 2: } \uparrow \text { COLL I; } \downarrow \text { cellularity, YM1 gene } \\
\text { expression, CD206-positive cells than group } 1\end{array}$ & [75] \\
\hline
\end{tabular}


TABLE 6: Continued.

\begin{tabular}{|c|c|c|c|c|}
\hline Experimental model & $\begin{array}{l}\text { Treatment } \\
\text { groups }\end{array}$ & Evaluations & Results & Ref \\
\hline $\begin{array}{l}\text { In vivo: } \\
29 \text { adult sheep }(2 \mathrm{yrs}) \text { with bilateral } \\
\text { Achilles tendon defects }(5 \mathrm{~mm} \\
\text { diameter) } \\
\text { hAECs }\left(1 \times 10^{7}\right)\end{array}$ & $\begin{array}{l}\text { Group 1: FG } \\
\text { Group 2: } \\
\text { FG+hAECs }\end{array}$ & $\begin{array}{l}\text { RT-PCR (COLL I, COLL III, } \\
\text { TNMD, THBS4, CD206, } \\
\text { IL10, VEGF, CD68, IL12b) } \\
\text { IHC (COLL I, COLL III, } \\
\text { VEGF) } \\
\text { Histology } \\
\text { Biomechanics (maximum } \\
\text { load, stiffness) }\end{array}$ & $\begin{array}{l}\qquad 1 \mathrm{mo} \\
\text { Group 2: rapid recovery of the tissue; sporadic } \\
\text { edema; regular longitudinal profile; } \uparrow \text { maximum } \\
\text { failure load; stiffness; regularly arranged fibers; } \\
\text { COLL I gene expression and protein, TNMD, } \\
\text { THBS4, CD206, and IL10 gene expression; } \downarrow \text { COLL } \\
\text { III and VEGF gene expression and protein, CD86, } \\
\text { and IL12b gene expression than group } 1\end{array}$ & {$[76]$} \\
\hline
\end{tabular}

Abbreviations: hSVF = human stromal vascular fraction; hBMSCs = human bone marrow mesenchymal stem cells; yrs = years; hrs = hours; wks = weeks; BMSCs = bone marrow mesenchymal stem cells; SVF = stromal vascular fraction; ALP = alkaline phosphatase; RT-PCR = reverse transcriptase-polymerase chain reaction; RUNX2 = runt-related transcription factor 2; COLL = collagen; OSX = Osterix; hADSCs = human adipose-derived mesenchymal stem cells; ADSCs = adipose-derived mesenchymal stem cells; $\mathrm{mm}=$ millimeters; $\mathrm{BA} / \mathrm{TA}=$ bone area/tissue area; $\mathrm{PLCL}=$ poly $(\mathrm{L}-$ lactide-co-caprolactone $)$; NM = normal medium; $\mathrm{CM}=$ chondrogenic medium; $\mathrm{OM}=$ osteogenic medium; $\mathrm{SOX}=$ sex-determining region $\mathrm{Y}$ boxes; $\mathrm{OCN}=$ osteocalcin; $\mathrm{ACAN}=$ aggrecan; $\mathrm{mo}=$ months; $\mathrm{IHC}=$ immunohistochemistry; Micro-CT = microcomputed tomography; HA = hydroxyapatite; $\mathrm{cm}=\mathrm{centimeters;} \mathrm{BV} / \mathrm{TV}=$ bone volume/tissue volume; $\mathrm{CD}=$ cluster of differentiation; $\beta \mathrm{TCP}=$ beta-tricalcium phosphate; $\mathrm{CFU}=$ colony forming units; $\mathrm{ml}=\mathrm{milliliters} ; \mathrm{BA}=$ bone area; $\mathrm{OPN}=$ osteopontin; PRP = platelet-rich plasma; $\mathrm{mg}=$ milligrams; PCL-DCB = polycaprolactone-decellularized bovine bone extracellular matrix; BV = bone volume; $\mathrm{VA}=$ vascular area; $\mathrm{PLA}=$ polylactic acid; $\mathrm{DBM}=$ demineralized bone matrix; $\mathrm{SD}=$ Sprague-Dawley; $\mathrm{BVF}=$ bone volume fraction; $\mathrm{Tb}$.Th = trabecular thickness; PLGA = poly(lactide-co-glycolide); NZW = New Zealand White; BMD = bone mineral density; Tb.Sp = trabecular separation; PMN = polymorphonuclear; $\mathrm{ONJ}=$ osteonecrosis of the jaw; $\mathrm{pz}=$ patients; $\mathrm{BCP}=$ biphasic calcium phosphate; $\mathrm{OV} / \mathrm{TV}=$ osteoid volume/tissue volume; $\mathrm{GAG}=$ glycosaminoglycans; $\mathrm{kg}=$ kilograms; $\mathrm{SB}=$ subchondral bone; $\mathrm{OA}=$ osteoarthritis; $\mathrm{kDa}=$ kilodaltons; $\mathrm{SDF}=$ stromal cell-derived factor; $\mathrm{PBS}=$ phosphatebuffered solution; NOD/SCID = nonobese diabetic/severe combined immunodeficiency; JKOM score = Japanese Knee Osteoarthritis Measure; VAS score = visual analog scale score; WOMAC score $=$ the Western Ontario and McMaster Universities Osteoarthritis score; SF = synovial fluid; KOOS score = Knee Injury and Osteoarthritis Outcome Score; $\mathrm{ADL}=$ Activities of Daily Living; $\mathrm{QOL}=$ quality of life; $\mathrm{BM}=$ bone marrow; ROM = range of motion; MOCART = magnetic resonance observation of cartilage repair tissue; MSCs = mesenchymal stem cells; AOFAS score = American Orthopedic Foot and Ankle Score; IKDC = International Knee Documentation Committee; EQ-VAS = EuroQol-visual analog scale; CT = cartilage thickness; DDFT $=$ deep digital flexor tendon; no. = number; FG = fibrin glue; $\mathrm{SNQ}=$ signal-to-noise quotient; $\mathrm{BMP}=$ bone morphogenetic protein; NIAT = noninsertional Achilles tendinopathy; $\mathrm{PD}=$ peri- and intratendinous flow; MR-Si = MR signal intensity; VISA-A score = Victorian Institute of Sports Assessment-Achilles questionnaire; SF-36 = Short Form 36 Health Survey; AECs = amniotic endothelial cells; hAECs = human amniotic endothelial cells; NRF2 = nuclear factor erythroid 2-related factor 2; KEAP1 = Kelch-like ECH-associated protein 1; PEMF = pulsed electromagnetic field; $\mathrm{Hz}=\mathrm{Hertz} ; \mathrm{min}=$ minutes; $\mathrm{hFOB}=$ human fetal osteoblastic; TGF $\beta 1=$ transforming growth factor $\beta 1 ; \mu \mathrm{g}=$ micrograms; VEGF = vascular endothelial growth factor; oAECs $=$ ovine AECs; $\mathrm{CaP}=$ calcium phosphate; Tb.N = trabecular number; hAFMSCs = human amniotic fluid mesenchymal stem cells; hAMSCs = human amniotic membrane mesenchymal stem cells; HAM = human amniotic membrane; ICRS score = International Cartilage Repair Society; PG = polygalacturonase; TNMD = tenomodulin; $\mathrm{SCXB}=$ scleraxis; TEA $=$ telomere area; $\mathrm{TEF}=$ feret maximum; MEAND $=$ mean densitometric value; $\mathrm{SDFT}=$ superficial digital flexor tendon; FDST $=$ flexor digitorum superficialis tendon.

morbidity, and the necessity to obtain a huge number of cells through in vitro expansion with associated risks.

Nowadays, a novel source of MSCs and new techniques to isolate such cells are being studied. Both SVF and AECs are spreading as new protagonists in the field of cell-based therapies for regenerative medicine, starting from the first applications in cardiology, and it is interesting to note that the only study in which both were used was aimed at cardiac repair [79].

In the field of regenerative medicine, the use of SVF has a relatively recent history. One of the pivotal studies in the introduction of the employment of SVF for clinical purposes dates to 2001, when Zuk et al. described the characterization of multilineage cells harvested from human adipose tissue and called them "processed lipoaspirate." In this study, it was demonstrated that the collected SVF contained not only adipose cells but also mesodermal or mesenchymal origin cells, as well as pericytes, endothelial cells, and smooth muscle cells. The evidence of the cells' capability to differentiate in vitro towards adipogenic, chondrogenic, myogenic, and osteogenic lineages opened the possibility of exploiting this as a new source for tissue regeneration [12]. The protocol described in this paper became a reference to isolate SVF and study its composition; however, until about ten years ago, the investigation was limited to in vitro evaluation of
SVF derived from mainly rodent models and tested for characterization and regeneration, with particular reference to cardiac muscle $[80,81]$. One of the first applications for a musculoskeletal system in vivo available in literature compared the efficacy of SVF and BMSCs in the treatment of $\mathrm{OA}$ in an equine model, without however obtaining any evident results in favour of neither treatment [82]. Since then, the number of studies has increased, while the application of SVF in clinical trials is fairly recent, as evidenced by this review.

As for AECs, despite the extensive literature history, it was only after the First International Workshop on Placenta-Derived Stem Cells when it was finally pointed out the field of application of mesenchymal stromal cells isolated from various parts of the placenta or epithelial cells isolated from the amniotic membrane in regenerative medicine. The findings suggested that the main applications were oriented mainly towards hepatic and cardiac repair and neurological disorders [83].

This review focuses on preclinical and clinical studies on an innovative source of cells (amniotic membrane) and a one-step surgical technique not based on in vitro expanded cells (SVF transplantation) for musculoskeletal tissue regeneration. 
In the last 10 years, 48 preclinical and clinical studies employed SVF (73\%) [7, 17, 28-60] or AECs (27\%) [61-76] in musculoskeletal tissue regeneration.

$\mathrm{n}$ general, in the studies of these cell sources, researchers prevalently performed in vivo studies $[7,29$, 31-39, 42-45, 56-58, 65-67, 71-76], followed by clinical ones $[40-42,46-54,59,60]$ and in vitro studies [17, 28-30, 43, 61-64, 68-70]. As for AECs, no clinical studies have yet been conducted, and the only two studies that analysed AEC behavior in cartilage were in vitro [68, 69]. For both cell types, most of the studies regarded bone regeneration [17, 28-42, 61-67], followed by cartilage $[7,43-54,68,69]$ and tendon [55-60, 70-76]. SVF was prevalently implanted with scaffolds for bone regeneration: HA [31, 32], $\beta$ TCP $[32,40,41]$, devitalized hypertrophic cartilage pellet [33], deproteinized sterilized bovine bone [34], PCL-DCB [35], DBM [36], PLA [36], PLGA [37], or fibrin hydrogel added with porous silicate HA microgranules [42]. Conversely, in cartilage regeneration, SVF was prevalently injected without scaffolds [43, 45], especially in the clinical studies [46-54], even if two studies employed COLL I/COLL III [44] or hyaluronic acid [7]. All the studies on tendon employed SVF without scaffolds [55-60].

In vivo AECs were seeded onto $\mathrm{CaP}[65]$ or $\beta \mathrm{TCP}[66$, 67] scaffolds in bone defects, while in tendon defects the authors injected AECs without scaffolds [70-76].

For both SVF and AECs, the results of the preclinical studies were obtained prevalently with histology and/or histomorphometry $[29,31-38,42-45,55,58,65-68,71-76]$, protein production detection through immunohistochemistry (IHC) $[7,17,31,34,36,38,42,55,58,60,65-68,71,75$, 76], and micro-CT $[17,31,33,35,37,38,44,65,66]$ and RT-PCR for gene expression analysis $[23,30,34,61-63,69$, 70, 73, 75, 76].

The preclinical results showed that SVF increased BMSCs' osteogenic differentiation, ALP activity, and the calcium content of THP1 cells $[28,29]$, and it was able to differentiate towards osteogenic, chondrogenic, or tenogenic lineages both in vitro and in heterotopic sites [17, 30-35, 43, 55]. SVF also increased BV, defect filling, Tb.Th, and cartilage or tendon regeneration in animal models of calvaria [35, 36], ulnar [37], ONJ-like [38], lameness [39], osteochondral [44], OA [7], cartilaginous [45], flexor tendon [55, 56], and supraspinatus tendon $[57,58]$ defects.

AECs have an osteogenic $[61,62,64,67]$, chondrogenic [69], or tenogenic [70] differentiation ability, in vitro and in heterotopic sites; increased BA, vessel formation, BMD in sinus defects $[65,66]$, and regenerated ex vivo cartilage defects [69]; and acute or chronic SDFT, FDST, and Achilles [71-74] tendon lesions.

Clinical studies were conducted in edentulous patients $[40,41]$ or in patients affected by humerus fractures [42], OA [46-52], full-thickness chondral defects [53], osteochondral lesions [54], NIAT [59], and Achilles tendon lesions [60]. The measurements were performed with micro-CT $[41,42]$, histology and histomorphometry [40-42], clinical scores (WOMAC, KOOS, VAS, Lysholm, JKOM, IKDC, $\mathrm{PD}$, VISA-A, AOFAS and EQ-VAS scores, and ROM)
[45-54, 59, 60] and radiography (MOCART score, MR$\mathrm{Si}$, and MR size) $[47,52,53,59]$.

In these studies, SVF could be employed not only as autologous cells but also as allogenic ones, as observed in some studies in which allogenic SVF was used in rabbits $[37,55,56]$, mice $[38,43]$, and in patients affected by OA $[46,48]$ or tendinopathy $[59,60]$. One of the major potential advantages of AECs is that, unlike other cells, they can be used as allogeneic or xenogenic cells. Allogenic AECs were implanted into sheep $[65,73-75]$ while xenogenic ones in rats [66], horses [71, 72], and sheep [76]. To obtain an idea on other ongoing clinical trials, a further search was carried out on http://www.clinicaltrial gov/. From this search, six clinical trials were found using SVF in OA patients, 2 in bone and 1 in tendon defects. However, the absence of clinical trials regarding AECs underlines that much remains to be explored on the potential of these cells.

More precisely, in OA patients, randomized clinical studies, single or triple blind in phase I, II, or III, are evaluating the effects of SVF injections into knees, also comparing SVF with corticosteroids, umbilical cord MSCs, BMSCs, or activated PRP. The enrolled patients are 20, 30, 40, 52, 200, and 480, and the evaluations are performed with clinical scores, ROM, adverse event recording, radiography, and arthroscopic cartilage repair assessment after 1, 3, 6, 9, 12, 18 , and 24 months.

In 8 and 5 patients, two clinical trials in phase II have evaluated the effect of SVF, seeded or not onto composite HA microgranules after embedding in a fibrin gel, in the treatment of proximal humeral fractures in osteoporotic patients or in craniofacial injuries. Radiological and clinical scores and average tissue thickness are evaluated at 6 and 12 weeks and 1, 3, 6, 9, and 12 months. [42]

One randomized, quadruple blind, phase II clinical trial has been performed in 52 patients to evaluate the ability of autologous SVF in improving the repair of chronic rotator cuff tears, and the evaluations of clinical measurements, change in muscle stiffness, and change in fatty infiltration are carried out at 6 weeks and at 6,12 , and 24 months [58].

The overview of the state-of-the-art in the study of these cell sources highlights some limitations in the comparison of SVF or AECs with other cell types, which is represented by the paucity of preclinical studies and the insufficient number of clinical trials conducted. However, despite these limits, some considerations about the comparison of AECs and SVF vs. other cell types can be made. For example, a superiority of SVF over ADSCs was found in inducing ALP activity and calcium content in THP1 cells [29], in osteogenic differentiation ability [17, 35], in chondrogenic differentiation [43], and in osteochondral or OA defect regeneration [7, 44]. In addition, SVF regenerated biomechanical properties of flexor tendon defects in a similar manner to BMSCs [56]. On the other hand, AECs showed higher osteogenic differentiation ability than ADSCs [61], but similar osteogenic differentiation to BMSCs and AFMSCs [67] and similar chondral defect regeneration to BMSCs and AMSCs [68]. 


\section{Conclusions}

SVF and AECs are two promising cells for regenerating bone, cartilage, and tendon. Both show advantages in terms of application in a one-step approach, which has become one of the main goals for streamlining and reducing bias in surgical procedures. In addition, harvesting procedures are easy and less invasive in comparison to other cell sources. In addition, as for AECs, many ethical concerns have been overcome when dealing with waste material; at the same time, the harvesting technique of SVF might make this source exploitable for autologous use also in patients with a particular pathology or undergoing therapies. Several preclinical studies affirm the regenerative ability of both SVF and AECs; less clinical studies on SVF exist, while no studies on AECs exist. Most of the clinical studies deal with SVF in patients affected by OA. Additionally, even if there are only a few studies that compare SVF or AECs with other cell types, they showed that SVF and AECs behave in a better or similar way to in vitro culture-expanded ADSCs or BMSCs, without showing the now known limitations linked to the cells expanded in culture. An advantage of AECs, compared to other cells, is its use in the form of allogeneic or xenogenic cells, although, in order to affirm this, clinical studies are necessary.

\section{Data Availability}

The data supporting this systematic review are from previously reported studies and datasets, which have been cited.

\section{Conflicts of Interest}

The authors declare that they have no conflict of interests.

\section{Acknowledgments}

This work was partially supported by the Ministry of HealthRicerca Corrente through the Rizzoli Orthopaedic Institute and by PRIN: Progetti di Ricerca di Rilevante Interesse Nazionale-Bando 2015 (Amniotic epithelial stem cells (AECs) vs. adipose-derived mesenchymal stem cells (ADSCs): translational potential as biological injective treatment for osteoarthritis).

\section{References}

[1] G. A. Brown, "AAOS clinical practice guideline: treatment of osteoarthritis of the knee: evidence-based guideline, 2nd edition," The Journal of the American Academy of Orthopaedic Surgeons, vol. 21, no. 9, pp. 577-579, 2013.

[2] S. Deng, Z. Sun, C. Zhang, G. Chen, and J. Li, "Surgical treatment versus conservative management for acute achilles tendon rupture: a systematic review and meta-analysis of randomized controlled trials," The Journal of Foot and Ankle Surgery, vol. 56, no. 6, pp. 1236-1243, 2017.

[3] S. Meena, A. Hooda, P. Sharma, S. Mittal, J. Sharma, and B. Chowdhury, "Operative versus non operative treatment of displaced intraarticular fracture of calcaneum: a metaanalysis of randomized controlled trials," Acta Orthopaedica Belgica, vol. 83, no. 1, pp. 161-169, 2017.
[4] A. I. Caplan and D. Correa, "The MSC: an injury drugstore," Cell Stem Cell, vol. 9, no. 1, pp. 11-15, 2011.

[5] S. A. Rodeo, "Cell therapy in orthopaedics: where are we in 2019?," Bone Joint J., vol. 101-B, no. 4, pp. 361-364, 2019.

[6] M. Strioga, S. Viswanathan, A. Darinskas, O. Slaby, and J. Michalek, "Same or not the same? Comparison of adipose tissue-derived versus bone marrow-derived mesenchymal stem and stromal cells," Stem Cells and Development, vol. 21, no. 14, pp. 2724-2752, 2012.

[7] X. Lv, J. He, X. Zhang et al., "Comparative efficacy of autologous stromal vascular fraction and autologous adiposederived mesenchymal stem cells combined with hyaluronic acid for the treatment of sheep osteoarthritis," Cell Transplantation, vol. 27, no. 7, pp. 1111-1125, 2018.

[8] C. H. Jo, Y. G. Lee, W. H. Shin et al., "Intra-articular injection of mesenchymal stem cells for the treatment of osteoarthritis of the knee: a proof-of-concept clinical trial," Stem Cells, vol. 32, no. 5, pp. 1254-1266, 2014.

[9] N. Yucel and H. M. Blau, "Skeletal muscle stem cells," in Principles of Regenerative Medicine, Academic Press, 3rd Ed edition, 2019.

[10] B. Biferali, D. Proietti, C. Mozzetta, and L. Madaro, "Fibro-adipogenic progenitors cross-talk in skeletal muscle: the social network," Frontiers in Physiology, vol. 10, p. 1074, 2019.

[11] R. N. Judson, M. Low, C. Eisner, and F. M. Rossi, "Isolation, culture, and differentiation of fibro/adipogenic progenitors (FAPs) from skeletal muscle," Methods in Molecular Biology, vol. 1668, pp. 93-103, 2017.

[12] P. A. Zuk, M. I. N. Zhu, H. Mizuno et al., "Multilineage cells from human adipose tissue: implications for cell-based therapies," Tissue Engineering, vol. 7, no. 2, pp. 211-228, 2001.

[13] Y. H. Lee, A. P. Petkova, and J. G. Granneman, "Identification of an adipogenic niche for adipose tissue remodeling and restoration," Cell Metabolism, vol. 18, no. 3, pp. 355-367, 2013.

[14] J. Guo, A. Nguyen, D. A. Banyard et al., "Stromal vascular fraction: a regenerative reality? Part 2: mechanisms of regenerative action," Journal of Plastic, Reconstructive \& Aesthetic Surgery, vol. 69, no. 2, pp. 180-188, 2016.

[15] D. A. Upchurch, W. C. Renberg, J. K. Roush, G. A. Milliken, and M. L. Weiss, "Effects of administration of adiposederived stromal vascular fraction and platelet-rich plasma to dogs with osteoarthritis of the hip joints," American Journal of Veterinary Research, vol. 77, no. 9, pp. 940-951, 2016.

[16] M. O. Sullivan, W. J. Gordon-Evans, L. P. Fredericks, K. Kiefer, M. G. Conzemius, and D. J. Griffon, "Comparison of mesenchymal stem cell surface markers from bone marrow aspirates and adipose stromal vascular fraction sites," Frontiers in Veterinary Science, vol. 2, p. 82, 2016.

[17] I. Roato, D. C. Belisario, M. Compagno et al., "Adiposederived stromal vascular fraction/xenohybrid bone scaffold: an alternative source for bone regeneration," Stem Cells International, vol. 2018, Article ID 4126379, 11 pages, 2018.

[18] Y. Jang, Y. G. Koh, Y. J. Choi et al., "Characterization of adipose tissue-derived stromal vascular fraction for clinical application to cartilage regeneration," In Vitro Cellular \& Developmental Biology - Animal, vol. 51, no. 2, pp. 142150, 2015.

[19] M. T. Rodrigues, S. J. Lee, M. E. Gomes, R. L. Reis, A. Atala, and J. J. Yoo, "Amniotic fluid-derived stem cells as a cell source for bone tissue engineering," Tissue Engineering. Part A, vol. 18, no. 23-24, pp. 2518-2527, 2012. 
[20] R. Keeley, N. Topoluk, and J. Mercuri, “Tissues reborn: fetal membrane-derived matrices and stem cells in orthopedic regenerative medicine," Critical Reviews in Biomedical Engineering, vol. 42, no. 3-4, pp. 249-270, 2014.

[21] Q. Zhou, X. Y. Liu, Y. X. Ruan et al., "Construction of corneal epithelium with human amniotic epithelial cells and repair of limbal deficiency in rabbit models," Human Cell, vol. 28, no. 1, pp. 22-36, 2015.

[22] M. Magatti, M. Caruso, S. De Munari et al., "Human amniotic membrane-derived, mesenchymal and epithelial cells exert different effects on monocyte-derived dendritic cell differentiation and function," Cell Transplantation, vol. 24, no. 9, pp. 1733-1752, 2015.

[23] F. Veronesi, G. Giavaresi, M. Tschon, V. Borsari, N. Nicoli Aldini, and M. Fini, "Clinical use of bone marrow, bone marrow concentrate, and expanded bone marrow mesenchymal stem cells in cartilage disease," Stem Cells and Development, vol. 22, no. 2, pp. 181-192, 2013.

[24] L. Cavinatto, B. B. Hinckel, R. E. Tomlinson, S. Gupta, J. Farr, and A. R. Bartolozzi, "The role of bone marrow aspirate concentrate for the treatment of focal chondral lesions of the knee: a systematic review and critical analysis of animal and clinical studies," Arthroscopy, vol. 35, no. 6, pp. 1860-1877, 2019.

[25] J. M. Cottom and B. S. Plemmons, "Bone marrow aspirate concentrate and its uses in the foot and ankle," Clinics in Podiatric Medicine and Surgery, vol. 35, no. 1, pp. 19-26, 2018.

[26] M. A. Imam, J. Holton, S. Horriat et al., "A systematic review of the concept and clinical applications of bone marrow aspirate concentrate in tendon pathology," SICOT-J, vol. 3, p. 58, 2017.

[27] S. I. Wolbank, A. Peterbauer, M. Fahrner et al., "Dose-dependent immunomodulatory effect of human stem cells from amniotic membrane: a comparison with human mesenchymal stem cells from adipose tissue," Tissue Engineering, vol. 13, no. 6, pp. 1173-1183, 2007.

[28] J. W. Choi, S. Shin, C. Y. Lee et al., "Rapid induction of osteogenic markers in mesenchymal stem cells by adipose- derived stromal vascular fraction cells," Cellular Physiology and Biochemistry, vol. 44, no. 1, pp. 53-65, 2018.

[29] Y. Zhang, E. C. Grosfeld, W. A. Camargo, H. Tang, A. M. P. Magri, and J. J. P. van den Beucken, "Efficacy of intraoperatively prepared cell-based constructs for bone regeneration," Stem Cell Research \& Therapy, vol. 9, no. 1, p. 283, 2018.

[30] W. J. Jurgens, R. J. Kroeze, R. A. Bank, M. J. P. F. Ritt, and M. N. Helder, "Rapid attachment of adipose stromal cells on resorbable polymeric scaffolds facilitates the one-step surgical procedure for cartilage and bone tissue engineering purposes," Journal of Orthopaedic Research, vol. 29, no. 6, pp. 853-860, 2011.

[31] T. Ismail, R. Osinga, T. Todorov Jr. et al., "Engineered, axiallyvascularized osteogenic grafts from human adipose-derived cells to treat avascular necrosis of bone in a rat model," Acta Biomaterialia, vol. 63, pp. 236-245, 2017.

[32] A. M. Müller, A. Mehrkens, D. J. Schäfer et al., “Towards an intraoperative engineering of osteogenic and vasculogenic grafts from the stromal vascular fraction of human adipose tissue," European Cells \& Materials, vol. 19, pp. 127-135, 2010.

[33] A. Todorov, M. Kreutz, A. Haumer et al., "Fat-derived stromal vascular fraction cells enhance the bone-forming capacity of devitalized engineered hypertrophic cartilage matrix," Stem Cells Translational Medicine, vol. 5, no. 12, pp. 1684-1694, 2016.
[34] S. J. Najman, V. J. Cvetković, J. G. Najdanović et al., "Ectopic osteogenic capacity of freshly isolated adipose-derived stromal vascular fraction cells supported with platelet-rich plasma: a simulation of intraoperative procedure," Journal of CranioMaxillo-Facial Surgery, vol. 44, no. 10, pp. 1750-1760, 2016.

[35] E. Nyberg, A. Farris, A. O'Sullivan, R. Rodriguez, and W. Grayson, "Comparison of stromal vascular fraction and passaged adipose-derived stromal/stem cells as point-of-care agents for bone regeneration," Tissue Engineering. Part A, vol. 25, no. 21-22, pp. 1459-1469, 2019.

[36] S. C. Rhee, Y. H. Ji, N. A. Gharibjanian, E. S. Dhong, S. H. Park, and E. S. Yoon, "In vivo evaluation of mixtures of uncultured freshly isolated adipose-derived stem cells and demineralized bone matrix for bone regeneration in a rat critically sized calvarial defect model," Stem Cells and Development, vol. 20, no. 2, pp. 233-242, 2011.

[37] A. Kim, D. H. Kim, H. R. Song et al., "Repair of rabbit ulna segmental bone defect using freshly isolated adipose-derived stromal vascular fraction," Cytotherapy, vol. 14, no. 3, pp. 296-305, 2012.

[38] S. Kuroshima, M. Sasaki, K. Nakajima, S. Tamaki, H. Hayano, and T. Sawase, "Transplantation of noncultured stromal vascular fraction cells of adipose tissue ameliorates osteonecrosis of the jaw-like lesions in mice," Journal of Bone and Mineral Research, vol. 33, no. 1, pp. 154-166, 2018.

[39] P. Tyrnenopoulou, M. Karayannopoulou, S. Angelopoulou et al., "Successful management of an equine carpal chip fracture by intra-articularly injected adipose-derived stromal vascular fraction after arthroscopic removal," Iranian Journal of Veterinary Research, vol. 17, no. 1, pp. 59-61, 2016.

[40] E. Farré-Guasch, N. Bravenboer, M. N. Helder, E. A. J. M. Schulten, C. M. ten Bruggenkate, and J. Klein-Nulend, "Blood vessel formation and bone regeneration potential of the stromal vascular fraction seeded on a calcium phosphate scaffold in the human maxillary sinus floor elevation model," Materials, vol. 11, no. 1, p. 161, 2018.

[41] H. J. Prins, E. A. J. M. Schulten, C. M. ten Bruggenkate, J. Klein-Nulend, and M. N. Helder, "Bone regeneration using the freshly isolated autologous stromal vascular fraction of adipose tissue in combination with calcium phosphate ceramics," Stem Cells Translational Medicine, vol. 5, no. 10, pp. 13621374, 2016.

[42] F. Saxer, A. Scherberich, A. Todorov et al., "Implantation of stromal vascular fraction progenitors at bone fracture sites: from a rat model to a first-in-man study," Stem Cells, vol. 34, no. 12, pp. 2956-2966, 2016.

[43] L. Wu, H. J. Prins, J. Leijten et al., "Chondrocytes cocultured with stromal vascular fraction of adipose tissue present more intense chondrogenic characteristics than with adipose stem cells," Tissue Engineering. Part A, vol. 22, no. 3-4, pp. 336348, 2016.

[44] W. J. F. M. Jurgens, R. J. Kroeze, B. Zandieh-Doulabi et al., "One-step surgical procedure for the treatment of osteochondral defects with adipose-derived stem cells in a caprine knee defect: a pilot study," Biores Open Access, vol. 2, no. 4, pp. 315-325, 2013.

[45] P. van Pham, K. Hong-Thien Bui, D. Quoc Ngo, L. Tan Khuat, and N. Kim Phan, "Transplantation of Nonexpanded Adipose Stromal Vascular Fraction and Platelet- Rich Plasma for Articular Cartilage Injury Treatment in Mice Model," Journal of Medical Engineering, vol. 2013, Article ID 832396, 7 pages, 2013. 
[46] N. Yokota, M. Yamakawa, T. Shirata, T. Kimura, and H. Kaneshima, "Clinical results following intra-articular injection of adipose-derived stromal vascular fraction cells in patients with osteoarthritis of the knee," Regenerative Therapy, vol. 6, pp. 108-112, 2017.

[47] I. Roato, D. C. Belisario, M. Compagno et al., "Concentrated adipose tissue infusion for the treatment of knee osteoarthritis: clinical and histological observations," International Orthopaedics, vol. 43, no. 1, pp. 15-23, 2019.

[48] H. Bansal, K. Comella, J. Leon et al., "Intra-articular injection in the knee of adipose derived stromal cells (stromal vascular fraction) and platelet rich plasma for osteoarthritis," Journal of Translational Medicine, vol. 15, no. 1, p. 141, 2017.

[49] N. Gibbs, R. Diamond, E. O. Sekyere, and W. D. Thomas, "Management of knee osteoarthritis by combined stromal vascular fraction cell therapy, platelet-rich plasma, and musculoskeletal exercises: a case series," Journal of Pain Research, vol. 8, pp. 799-806, 2015.

[50] P. D. Nguyen, T. D.-X. Tran, H. T.-N. Nguyen et al., "Comparative clinical observation of arthroscopic microfracture in the presence and absence of a stromal vascular fraction injection for osteoarthritis," Stem Cells Translational Medicine, vol. 6, no. 1, pp. 187-195, 2017.

[51] T. D. X. Tran, C. M. Wu, N. K. Dubey et al., "Time- and Kellgren-Lawrence grade-dependent changes in intraarticularly transplanted stromal vascular fraction in osteoarthritic patients," Cell, vol. 8, no. 4, p. 308, 2019.

[52] Z. Hong, J. Chen, S. Zhang et al., "Intra-articular injection of autologous adipose-derived stromal vascular fractions for knee osteoarthritis: a double-blind randomized self-controlled trial," International Orthopaedics, vol. 43, no. 5, pp. 1123-1134, 2019.

[53] Y. S. Kim, H. J. Lee, Y. J. Choi, Y. I. Kim, and Y. G. Koh, "Does an injection of a stromal vascular fraction containing adiposederived mesenchymal stem cells influence the outcomes of marrow stimulation in osteochondral lesions of the talus? A clinical and magnetic resonance imaging study," The American Journal of Sports Medicine, vol. 42, no. 10, pp. 24242434, 2014.

[54] R. Z. Salikhov, R. F. Masgutov, M. A. Chekunov et al., "The stromal vascular fraction from fat tissue in the treatment of osteochondral knee defect: case report," Frontiers in Medicine, vol. 5, p. 154, 2018.

[55] M. Behfar, F. Sarrafzadeh-Rezaei, R. Hobbenaghi, N. Delirezh, and B. Dalir-Naghadeh, "Adipose-derived stromal vascular fraction improves tendon healing in rabbits," Chinese Journal of Traumatology, vol. 14, no. 6, pp. 329-335, 2011.

[56] M. Behfar, S. Javanmardi, and F. Sarrafzadeh-Rezaei, "Comparative study on functional effects of allotransplantation of bone marrow stromal cells and adipose derived stromal vascular fraction on tendon repair: a biomechanical study in rabbits," Cell Journal, vol. 16, no. 3, pp. 263-270, 2014.

[57] L. Y. Lu, M. Ma, J. F. Cai et al., "Effects of local application of adipose-derived stromal vascular fraction on tendon-bone healing after rotator cuff tear in rabbits," Chinese Medical Journal, vol. 131, no. 21, pp. 2620-2622, 2018.

[58] L. Y. Lu, C. Y. Kuang, and F. Yin, "Magnetic resonance imaging and biomechanical analysis of adipose-derived stromal vascular fraction applied on rotator cuff repair in rabbits," Chinese Medical Journal, vol. 131, no. 1, pp. 69-74, 2018.

[59] D. Albano, C. Messina, F. G. Usuelli et al., "Magnetic resonance and ultrasound in achilles tendinopathy: predictive role and response assessment to platelet-rich plasma and adipose- derived stromal vascular fraction injection," European Journal of Radiology, vol. 95, pp. 130-135, 2017.

[60] F. G. Usuelli, M. Grassi, C. Maccario et al., "Intratendinous adipose-derived stromal vascular fraction (SVF) injection provides a safe, efficacious treatment for achilles tendinopathy: results of a randomized controlled clinical trial at a 6-month follow-up," Knee Surgery, Sports Traumatology, Arthroscopy, vol. 26, no. 7, pp. 2000-2010, 2018.

[61] N. Topoluk, R. Hawkins, J. Tokish, and J. Mercuri, “Amniotic mesenchymal stromal cells exhibit preferential osteogenic and chondrogenic differentiation and enhanced matrix production compared with adipose mesenchymal stromal cells," The American Journal of Sports Medicine, vol. 45, no. 11, pp. 2637-2646, 2017.

[62] Q. Wang, W. Wu, X. Han et al., "Osteogenic differentiation of amniotic epithelial cells: synergism of pulsed electromagnetic field and biochemical stimuli," BMC Musculoskeletal Disorders, vol. 15, no. 1, p. 271, 2014.

[63] G. Wang, F. Zhao, D. Yang, J. Wang, L. Qiu, and X. Pang, "Human amniotic epithelial cells regulate osteoblast differentiation through the secretion of TGF $\beta 1$ and microRNA-34a5p," International Journal of Molecular Medicine, vol. 41, no. 2, pp. 791-799, 2018.

[64] F. Luan, K. Ma, J. Mao, F. Yang, M. Zhang, and H. Luan, “Differentiation of human amniotic epithelial cells into osteoblasts is induced by mechanical stretch via the $\mathrm{Wnt} / \beta$-catenin signalling pathway," Molecular Medicine Reports, vol. 18, no. 6, pp. 5717-5725, 2018.

[65] B. Barboni, C. Mangano, L. Valbonetti et al., "Synthetic bone substitute engineered with amniotic epithelial cells enhances bone regeneration after maxillary sinus augmentation," Plos One, vol. 8, no. 5, article e63256, 2013.

[66] S. Jiawen, Z. Jianjun, D. Jiewen et al., "Osteogenic differentiation of human amniotic epithelial cells and its application in alveolar defect restoration," Stem Cells Translational Medicine, vol. 3, no. 12, pp. 1504-1513, 2014.

[67] J. Si, J. Dai, J. Zhang et al., "Comparative investigation of human amniotic epithelial cells and mesenchymal stem cells for application in bone tissue engineering," Stem Cells International, vol. 2015, Article ID 565732, 14 pages, 2015.

[68] E. Muinos-Lopez, T. Hermida-Gomez, I. Fuentes-Boquete, J. de Toro-Santos, F. J. Blanco, and S. M. Diaz-Prado, "Human amniotic mesenchymal stromal cells as favorable source for cartilage repair," Tissue Engineering. Part A, vol. 23, no. 1718, pp. 901-912, 2017.

[69] J. Zhou, G. Yu, C. Cao, J. Pang, and X. Chen, "Bone morphogenetic protein-7 promotes chondrogenesis in human amniotic epithelial cells," International Orthopaedics, vol. 35, no. 6, pp. 941-948, 2011.

[70] B. Barboni, V. Russo, V. Curini et al., "Achilles tendon regeneration can be improved by amniotic epithelial cell allotransplantation," Cell Transplantation, vol. 21, no. 11, pp. 2377-2395, 2012.

[71] A. Muttini, L. Valbonetti, M. Abate et al., "Ovine amniotic epithelial cells: In vitro characterization and transplantation into equine superficial digital flexor tendon spontaneous defects," Research in Veterinary Science, vol. 94, no. 1, pp. 158-169, 2013.

[72] A. Muttini, V. Russo, E. Rossi et al., "Pilot experimental study on amniotic epithelial mesenchymal cell transplantation in natural occurring tendinopathy in horses. Ultrasonographic 
and histological comparison," Muscles, Ligaments and Tendons Journal, vol. 5, no. 1, pp. 5-11, 2015.

[73] B. Barboni, V. Curini, V. Russo et al., "Indirect co-culture with tendons or tenocytes can program amniotic epithelial cells towards stepwise tenogenic differentiation," Plos One, vol. 7, no. 2, article e30974, 2012.

[74] A. Muttini, M. Mattioli, L. Petrizzi et al., "Experimental study on allografts of amniotic epithelial cells in calcaneal tendon lesions of sheep," Veterinary Research Communications, vol. 34, no. S1, pp. 117-S120, 2010.

[75] A. Mauro, V. Russo, L. di Marcantonio et al., "M1 and M2 macrophage recruitment during tendon regeneration induced by amniotic epithelial cell allotransplantation in ovine," Research in Veterinary Science, vol. 105, pp. 92-102, 2016.

[76] B. Barboni, V. Russo, V. Gatta et al., "Therapeutic potential of hAECs for early Achilles tendon defect repair through regeneration," Journal of Tissue Engineering and Regenerative Medicine, vol. 12, no. 3, pp. 1-15, 2017.

[77] J. D. Rees, N. Maffulli, and J. Cook, "Management of tendinopathy," The American Journal of Sports Medicine, vol. 37, no. 9, pp. 1855-1867, 2009.

[78] J. Vamze, M. Pilmane, and A. Skagers, "Biocompatibility of pure and mixed hydroxyapatite and $\alpha$-tricalcium phosphate implanted in rabbit bone," Journal of Materials Science. Materials in Medicine, vol. 26, no. 2, p. 73, 2015.

[79] C. Castellani, G. Vescovo, B. Ravara et al., "The contribution of stem cell therapy to skeletal muscle remodeling in heart failure," International Journal of Cardiology, vol. 168, no. 3, pp. 2014-2021, 2013.

[80] M. A. Vidal, G. E. Kilroy, M. J. Lopez, J. R. Johnson, R. M. Moore, and J. M. Gimble, "Characterization of equine adipose tissue-derived stromal cells: adipogenic and osteogenic capacity and comparison with bone marrow-derived mesenchymal stromal cells," Veterinary Surgery, vol. 36, no. 7, pp. 613-622, 2007.

[81] N. J. Palpant, S. Yasuda, O. MacDougald, and J. M. Metzger, "Non-canonical Wnt signaling enhances differentiation of Sca1+/c-kit+ adipose-derived murine stromal vascular cells into spontaneously beating cardiac myocytes," Journal of Molecular and Cellular Cardiology, vol. 43, no. 3, pp. 362370, 2007.

[82] D. D. Frisbie, J. D. Kisiday, C. E. Kawcak, N. M. Werpy, and C. W. McIlwraith, "Evaluation of adipose-derived stromal vascular fraction or bone marrow-derived mesenchymal stem cells for treatment of osteoarthritis," Journal of Orthopaedic Research, vol. 27, no. 12, pp. 1675-1680, 2009.

[83] O. Parolini, F. Alviano, G. P. Bagnara et al., "Concise review: isolation and characterization of cells from human term placenta: outcome of the first international Workshop on Placenta Derived Stem Cells," Stem Cells, vol. 26, no. 2, pp. 300-311, 2008. 